\title{
IMPACT OF ECONOMIC COMPETITIVENESS ON INDIAN AND CHINESE PRODUCTION DEVELOPMENT
}

\section{MANISHKUMAR SAINI}

\begin{abstract}
:
The graduation thesis aims to determine the Impact of economic competitiveness on Indian and Chinese production Development. This Graduation thesis determines economic competitiveness of two major global economies of the world that is India and China with help of Key process Indices like GDP, Labour Product, Employment, Life expectancy, Median household income, Income Gini, Poverty rate, Wealth Gini, Adjusted net saving, Dependency Ratio, Public Debt, the Carbon intensity of GDP. Competitiveness refers to the skills to dominate and retain position within the market, to extend market share and gain, and eventually to consolidate commercial activities. The rising standard of living with high levels of employment means that the country is competitive. At the macro-level national competitiveness is outlined because of the ability of states to attain economic progress quicker than alternative countries and to increase the movement of international trade. Competitiveness primarily involves the economic development of all the factors in the demand for national competitiveness. The importance of the idea of competitiveness is currently firmly embedded within the economic key process Indices of countries around the world. Therefore, measuring, understanding and analyzing competition at various economic levels become an important issue with intention to search out the ways that can potentially enhance the economic performance of states, regions, and country as a whole. The assessment of competitiveness is undertaken based on the measure of competitiveness to get a more complete overview of competitiveness. Accordingly, the competitiveness of India and China is measured using economic factors like GDP, Labour market, Employment, Life expectancy, Median household income, Income Gini, Poverty rate, Wealth Gini, Adjusted net saving, dependency Ratio, public debt, the carbon intensity of GDP. Based on the comparison of economic competitiveness of India and china it can be concluded that China is economically ahead of India in terms of Labour product, employment, Gross Domestic Product, adjusted net saving, life expectancy, Income Gini, Wealth Gini, Depth ratio, public depth and low poverty rate as compared to India. Whereas, India is economically ahead of China in terms of the carbon intensity of the Gross Domestic Product. Hence China has lead over India in terms of economic competitiveness.
\end{abstract}

\section{Keywords:}

Competitiveness, Prosperity, Macroeconomic, Employment, Inclusion, Inflation

JEL Classification: F00

\section{Authors:}

MANISHKUMAR SAINI, Faculty of Production Engineering, Warsaw University of Technology, Poland, Email: manish.saini306@gmail.com 


\section{Citation:}

MANISHKUMAR SAINI (2020). Impact of Economic Competitiveness on Indian and Chinese Production Development. International Journal of Business and Management, Vol. VIII(1), pp. 122-154., 10.20472/BM.2020.8.1.007 


\section{Introduction}

During the last thirty years, competitiveness had become one in all the foremost analyzed economic phenomena. Competitiveness refers to the skills to dominate and retain position within the market, to extend market share and gain, and eventually to consolidate commercial activities. The national competitiveness is political economy development that depends on exchange rates, interest rates, budget deficits, and people. Rising the standard of living with high levels of employment means that the country is competitive. At the macro level, national competitiveness is outlined because of the ability of states to attain economic progress quicker than alternative countries and to increase international trade. Competitiveness primarily involves the economic development of all the factors in the demand for national competitiveness ${ }^{1}$. The importance of the idea of competitiveness is currently firmly embedded within the economic key process indices of countries around the world. Therefore, measuring, understanding and analyzing competitiveness at various economic levels became an important issue to search out the ways that can potentially enhance the economic performance of states, regions, and countries as a whole. Competitiveness of India and China is calculated using Key process Indices like GDP, Labour market, Employment, Life expectancy, Median household income, Income Gini, Poverty rate, Wealth Gini, Adjusted net saving, dependency Ratio, public debt, the carbon intensity of GDP.

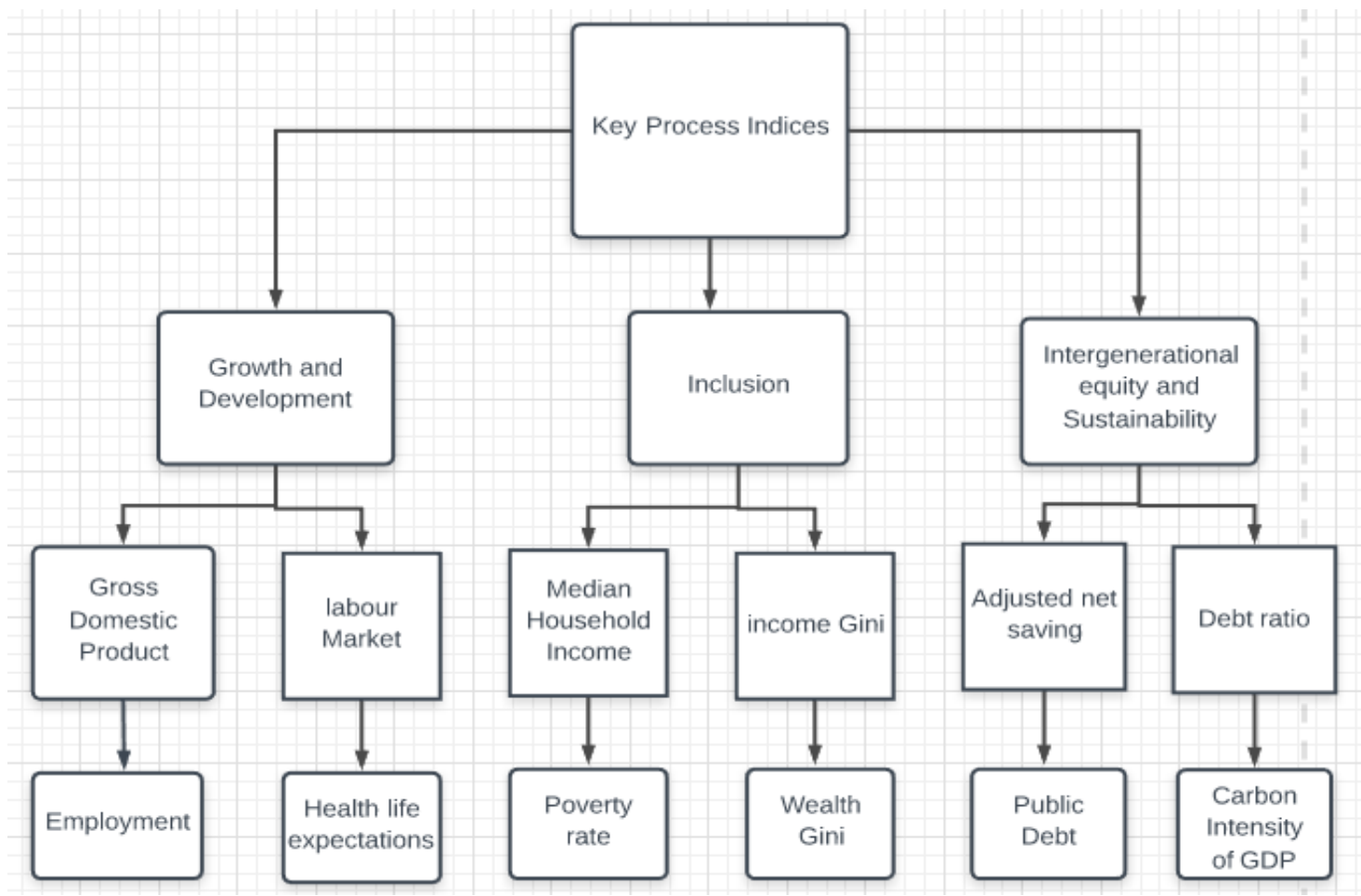

Figure1: Economic Factors affecting the competitiveness

Source: Own Elaboration

This paper discusses economic competitiveness of two economies - India and China with help of Key process indices like GDP, labor product, employment, life expectancy, median household income, income Gini, poverty rate, wealth Gini, net savings, debt ratio, public debt, the carbon intensity of Gross Domestic Product. ${ }^{2}$ Achieving a competitive advantage needs a

${ }^{1}$ Own Elaboration

2 Own Elaboration 
transparent understanding of what competitiveness means and the way to analyse it effectively. Such clarity is the key to make an economic environment that boosts innovation, potential, and prosperity.

Both China and India have governments deeply engaged in orchestrating the digital economy and in citizens' knowledge. It's well-known that China's government has bold objectives for the country's digital future. The Chinese President Xi Jinping aims to make associate degree impregnable cyber-defense system, provide itself a bigger voice in web governance, foster a lot of first firms, and lead the world in advanced technologies ${ }^{3}$. Meanwhile, India's government additionally has bold objectives for the country's digital economy. Relative to its Chinese counterparts, India's authorities are targeted on the basics of cheap access to digital tools associate degree in making an open and interoperable infrastructure. There also are plans to ascertain one hundred good cities across the Republic of India unitedly with public agencies and personnel firms.

\footnotetext{
${ }^{3}$ Own Elaboration
} 


\section{Competitiveness as an Economic Phenomenon-Literature Review}

\subsection{Definition of Competitiveness}

For the nation, competitiveness can be defined as the ability of the nation's citizens to achieve a high standard of living. Competitiveness is measured by the level and growth of the nation's standard of living, and the ability of the nation's firms to increase their world market penetration through foreign direct investment. Comparative advantage indicates that any nation will be competitive in some industries and uncompetitive in others.

\subsection{Role of Competitiveness:}

A nation's standard of living is increasingly dependent on the competitiveness of its firms. Competitiveness is vital if the nation's firms are to take benefit of the opportunities presented by the international economy. Competitiveness in industries subject to international trade, therefore foreign direct investment can provide substantial leverage for economic growth. This is accurate for small nations, where competitiveness allows firms to overcome the limitations of their small home markets to achieve maximum potential. Competitiveness is also vital if a nation's firms are to guard against international economy threats ${ }^{4}$.

\subsection{Determinants of Competitiveness:}

From the last thirty years, competitiveness had become one in every of the foremost analyzed economic phenomena. A broad notion of competitiveness refers to the inclination and skills to contend, to win and retain position within the market, to extend market share and profitableness, and eventually to consolidate commercially eminent activities. Most likely the most effective summary of various opinions in understanding the construct of the competitiveness was given by Porter back within the nineties. He noted that though there's a transparent and in agreement definition of the company's competitiveness, it's not the case with the definition of the competitiveness of countries. He points out that the national competitiveness in economic development depends on exchange rates, interest rates, budget deficits, and people. United Nations agency believes that it's the operation of low-cost and huge personnel. Some believe that it's the potential to link competitiveness with an abundance of natural resources. Moreover, he notes that some relate national competitiveness with government policies that regulate the protection, promotion of imports and subsidies. Finally, he points out the likelihood of decoding this idea in its relevance management practices, together with human resource management. In his work Porter (1990) concludes that national competitiveness prosperity isn't genetic, however, it's rather created by strategic decisions, and nation may be seen through the prism of the four components of each national economy: issue conditions, demand conditions, connected and supporting industries and firm strategy, structure and competition ${ }^{5}$. What is more, the globe Economic Forum defines competitiveness as a set of establishments, policies, and factors that confirm the extent of productivity. This implies that the state is competitive if its population will on a property basis enjoy a high and rising standard of living with high levels of employment. At the macro-level national competitiveness is outlined because of the ability of the nation to realize the economic process quicker than different countries and to extend the well-being so that its economic structure changes and highly adaptable to international trade. However, there are opposing views, like the United Nations agency is a member of the cluster that believes that there's a major distinction between the perception of the competitiveness of the economy and corporations and therefore the competitiveness is a nonsense term once applied within the context of the financial system. Despite totally different opinions in relevancy the definition of national competitiveness, public

\footnotetext{
4 Own Elaboration

${ }^{5}$ Khanna. T., China, and India, the power of two. Harvard Business Review, 2009, p.469-72.
} 
and politicians show a high interest in the country's competitiveness level. Competitiveness primarily involves the advance and economic development of all the factors in the demand for national competitiveness. The importance of competitiveness is currently firmly embedded within the economic policies of nations around the world. Therefore, measuring, understanding and analyzing competition in several geographic levels became an important issue for policy manufacturers to search out the ways for potential enhancement of economic performance of nations and regions. For this reason, varied international establishments produce indices that measure and rank individual countries under various aspects of competitiveness.

Prahalad and Hamel emphasized that the core competencies of a firm are the idea for a firm to become competitive. Core competencies are those explicit strengths of an organization that offers it a footing over competitors. These give a competitive advantage to the corporate. Core competencies are the collective learning within the organization, particularly the way to coordinate numerous production skills and integrate multiple streams of technologies ${ }^{6}$. As an example, Sony's capability to miniaturize and Philips' optical-media capabilities are their core competencies. Core merchandises are the parts or sub-assemblies that contribute to the worth of the top products. as an example, Honda's engines are its core merchandise. The Global Competitiveness Report, brought out annually by the World Economic Forum (WEF) could be a comprehensive analysis of the international competitiveness of nations. Comparative competitiveness positions of the Republic of India and relevant countries, additionally as trends in India's position on various factors are given in Table 1. Low ranks of the Republic of India, overall and on some important factors, and decline is clear from Table-1. Low rank on factors like individuals and infrastructure is cause for concern. Ranks on different important factors like management, finance, science \&technology; are far away from satisfactory. Similarly, low ranks on aggressiveness and attractiveness dimensions are worrisome. Such competitiveness reports at the country level are a valuable supply of knowledge concerning the relative position of the countries.

Economic growth and development are tangled and might be assessed from two perspectives: the thought and also the essential. Within the thought approach, economic process and development are involved with the unsuccessful material desires of individuals. Countries want the economic process to make sure that generates enough resources to full-fill the requirements of their population. In-line with this approach ${ }^{7}$, development is linear: there's a selected path that countries will follow to realize development

\footnotetext{
${ }^{6}$ Own Elaboration

${ }^{7}$ Adam. P., Become. W., Economic growth, industrial structure, and technical efficiency: empirical evidence from Ghana, Senegal, and Morocco on the causal dynamics, 2012. p.369-78
} 
Table 1: Competitiveness ranks of India and selected countries ${ }^{8}$

\begin{tabular}{|l|c|c|c|c|c|c|c|}
\hline & $\begin{array}{c}2010 \\
\text { INDIA }\end{array}$ & $\begin{array}{c}2011 \\
\text { INDIA }\end{array}$ & $\begin{array}{c}2012 \\
\text { INDIA }\end{array}$ & $\begin{array}{l}2010 \\
\text { JAPAN }\end{array}$ & $\begin{array}{c}2010 \\
\text { KOREA }\end{array}$ & $\begin{array}{c}2010 \\
\text { CHINA }\end{array}$ & $\begin{array}{r}2010 \\
\text { USA }\end{array}$ \\
\hline Government & 16 & 29 & 25 & 25 & 24 & 8 & 11 \\
\hline Finance & 28 & 39 & 36 & 25 & 55 & 39 & 3 \\
\hline Internationalisation & 39 & 41 & 39 & 33 & 46 & 20 & 1 \\
\hline Infrastructure & 45 & 47 & 49 & 22 & 31 & 40 & 1 \\
\hline Management & 32 & 39 & 29 & 24 & 34 & 30 & 1 \\
\hline People & 44 & 45 & 48 & 09 & 22 & 24 & 6 \\
\hline Science \& Tech. & 32 & 26 & 29 & 04 & 26 & 11 & 3 \\
\hline Domestic Economy & 33 & 28 & 18 & 15 & 36 & 7 & 1 \\
\hline OVERALL & $\mathbf{3 8}$ & $\mathbf{4 1}$ & $\mathbf{4 1}$ & $\mathbf{1 8}$ & $\mathbf{3 5}$ & $\mathbf{2 4}$ & $\mathbf{1}$ \\
\hline Out of countries & & & 46 & 46 & 46 & 46 & 46 \\
\hline Attractiveness & 39 & 42 & 37 & 26 & 35 & 20 & 03 \\
\hline Aggressiveness & 42 & 43 & 05 & 32 & 29 & 1 \\
\hline
\end{tabular}

Source: ResearchGate, https://www.researchgate.net/publication/23777315_Competitiveness_of_India, accessed on 24/06/2019.

\footnotetext{
${ }^{8}$ Adam. P., Become. W., Economic growth, industrial structure, and technical efficiency: empirical evidence from Ghana, Senegal, and Morocco on the causal dynamics, 2012. p.369
} 


\section{Measures of Competitiveness}

\subsection{Growth and Development:}

\subsubsection{Gross Domestic Product:}

Gross Domestic Product (GDP) is the total financial value of all the finished merchandise and services created within a country's borders in an exceedingly specific fundamental measure ${ }^{9}$.

\subsubsection{Labour Market:}

Labour Market is the study of the labor force as part of the method of production. The labor force includes all people who work for gain, whether or not as workers, employers, or as a freelance ${ }^{10}$.

\subsubsection{Employment Rate:}

The employment to population ratio, that is the number of people of working age in the population who are employed is called the employment rate ${ }^{11}$. International Labour Organization states that people are considered employed if they've had an hour or more in gainful employment in the most recent week.

\subsubsection{Life Expectancy:}

The term life expectancy refers to the number of years an individual will expect to measure. By definition, lifespan relies on an associated estimate of the typical age that members of a specific population will be once they die. lifespan is one amongst the key measures of a population's health and enriches economic measures of prosperity ${ }^{12}$.

\subsection{Inclusion:}

\subsubsection{Median Household Income:}

A median home financial gain refers to the income level earned by a given household wherever half the homes within the space earn additional and half earn less. It's used rather than the typical home financial gain, as a result, it will provide an additional correct image of an area's actual economic standing ${ }^{13}$.

\subsubsection{Income Gini:}

The rising influence of the rich and stagnant incomes of the poor and sophistication have a causative result on crises, and thus directly hurt short and long growth ${ }^{14}$. Income inequality hampers financial condition reduction. It affects the pace of growth and the financial condition of the country.

\subsubsection{Poverty Rate:}

Poverty affects a nation's economy in many ways. Because, by definition, that portion of a nation's population living below the personal income has very little cash to pay, there's less demand for several products that may well be the case. That adversely affects the supply-side of the economic equation, which implies less cash paid to others to supply and distribute ${ }^{15}$.

\footnotetext{
${ }_{9}^{9}$ Nilekani, N., Imagining India: Ideas for the new century. International Business 6th edition, New Delhi 2013, p.144-58

${ }^{10}$ Adam. P., Become. W., Economic growth, industrial structure, and technical efficiency: empirical evidence from Ghana, Senegal, and Morocco on the causal dynamics, 2012, p.369-78

${ }_{11}$ Venkat Subbiah. H., Enterprise and Economic Change: 50 Years of FICCI. Vikas Publishing House, New Delhi, 1977, p.69-78

12 Own Elaboration

13 Khanna. T., China, and India, the power of two. Harvard Business Review, 2009, p.469-72.

${ }_{14}$ Own Elaboration

15 Own Elaboration.
} 


\subsubsection{Wealth Gini:}

The Gini index is a measure of distribution statistically. It is often used as a gauge of measuring income distribution economic inequality, and wealth distribution among a population ${ }^{16}$. The coefficient ranges from 0 to 1 , with 0 representing perfect equality and 1 representing perfect inequality.

\subsection{Intergenerational Equity and sustainability:}

\subsubsection{Adjusted Net Saving:}

Adjusted Net Saving (ANS) measures the true rate of saving in the associate economy. Adjusted Net Saving, proverbial informally as real saving, is an associate indicator that aims to assess associate economy's property that supported the ideas of extended national accounts ${ }^{17}$.

\subsubsection{Debt Ratio:}

The depth ratio proportion is the proportion of a nation's public depth to its total national output ${ }^{18}$. The higher the depth to GDP proportion, the more uncertain the nation will pay back its depth and the higher its danger of default.

\subsubsection{Public Debt:}

Public debt sometimes solely refers to debt. however, some countries conjointly embody the debt owed by states, provinces, and municipalities. Regardless of what it's referred to as debt is the accumulation of annual budget deficits ${ }^{19}$.

\subsubsection{Carbon Intensity of GDP:}

Emission intensity is the emission rate of a given waste product relative to the intensity of a particular activity, or associate industrial production process; for instance, grams of dioxide discharged per megajoule of energy created, or the magnitude relation of greenhouse emission emissions created to gross domestic product.

\footnotetext{
${ }^{16}$ Khanna. T., China, and India, the power of two. Harvard Business Review, 2009, p.469-72.

17 https://ec.europa.eu/environment/beyond_gdp/download/factsheets/bgdp-ve-ans.pdf, accessed on 14/06/2019.

${ }^{18}$ Barthelemy. J., Demerger. S., Foreign Direct Investment and Economic Growth: Theoretical Issues and

Empirical Application to China. Review of Development Economics. 2000, p.20-29.

19 Own Elaboration
} 


\section{Comparison of Economies of India and China based on measures of Competitiveness.}

\subsection{Indian economy competitiveness}

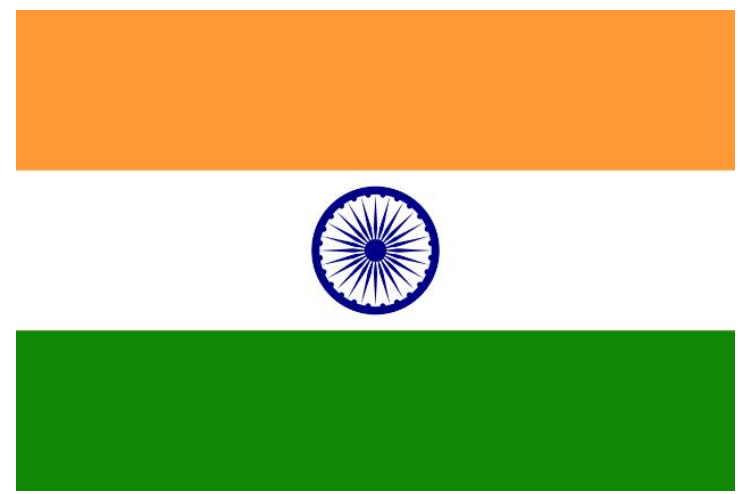

Figure 2: Flag of India

Source: maps of India, https://www.mapsofindia.com/maps/india/national-flag.html, accessed on $16 / 05 / 2019$.

In India, complete state-driven nationalization and state-driven economic process demand a state, which might have a lot of larger command over interest teams like industrialists, farmers and trade unions. Policies favoring economic process and development in India required to evolve bit by bit once building a social accord on those policies ${ }^{20}$. This is often a model of development driven by a relationship between the state and society, wherever the facility of the state, even in its commanding moments, was tempered by the facility of social actors. The Indian state has seen a lot of penetrated by social actors than several East and Southeast Asian states. In contrast to China, India may neither get rid of personal enterprise nor could it embrace the economic process with identical speed and violence.

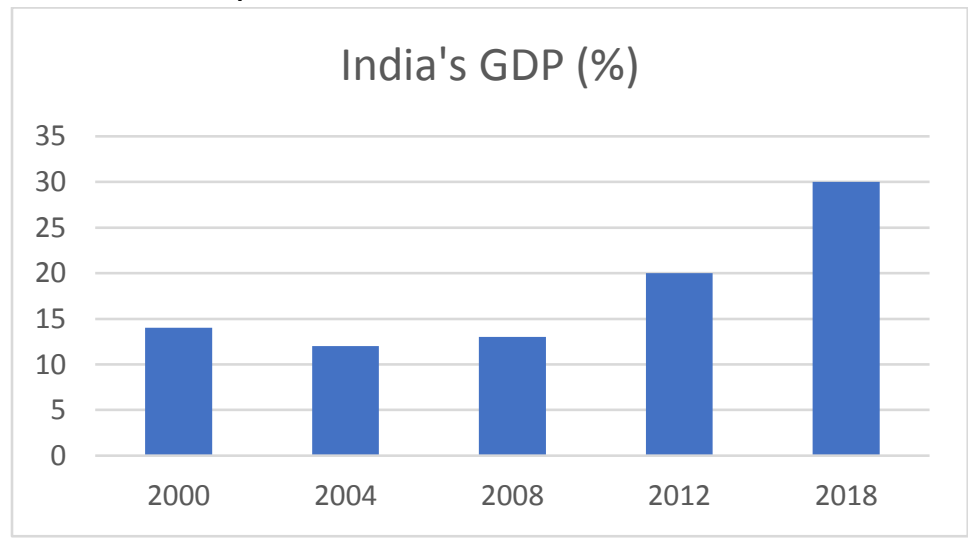

\section{Figure 3: India's GDP (\%)}

Source: tutor2u, https://www.tutor2u.net/economics/reference/india-economic-growth-anddevelopment, accessed on 26/02/2019.

India's democratic quality and also the chaotic nature of development policy are well-known. The literature on the event state driven by the East Asian expertise had been mostly preoccupied with the importance of autonomy - or the East Asian state's ability to keep up its independence from powerful social actors. India, on the opposite hand, was represented as a

\footnotetext{
${ }^{20} \mathrm{H}$. Venkat Subbiah, Enterprise, and Economic Change: 50 Years of FICCI (New Delhi: Vikas Publishing House, 1977), p.169-72.
} 
country whose industrialization and growth was blocked by politics and patronage. India's sustained growth on the far side of 1991 poses a puzzle for this literature.

\subsubsection{Growth and Development:}

The Gross Domestic Product within a country like the Asian nation is experiencing a faster rate of growth within recent years. Concerning the composition of GDP, the proportion shares of assorted sectors have principally changed. The proportion share of the agriculture at intervals of the full GDP has declined, on the contrary, the proportion share of services at intervals of the GDP is rising faster. With this shift, the Indian economy was thought-about, to be big, to be agriculture-based economy but with the gap of the economy post-economic reforms of 1991, has become predominantly services-based. This change in the composition of GDP impact nearly everyone at intervals, the role of services and manufacturing sector in the economy and therefore it impacts the economic health of the country ${ }^{21}$.

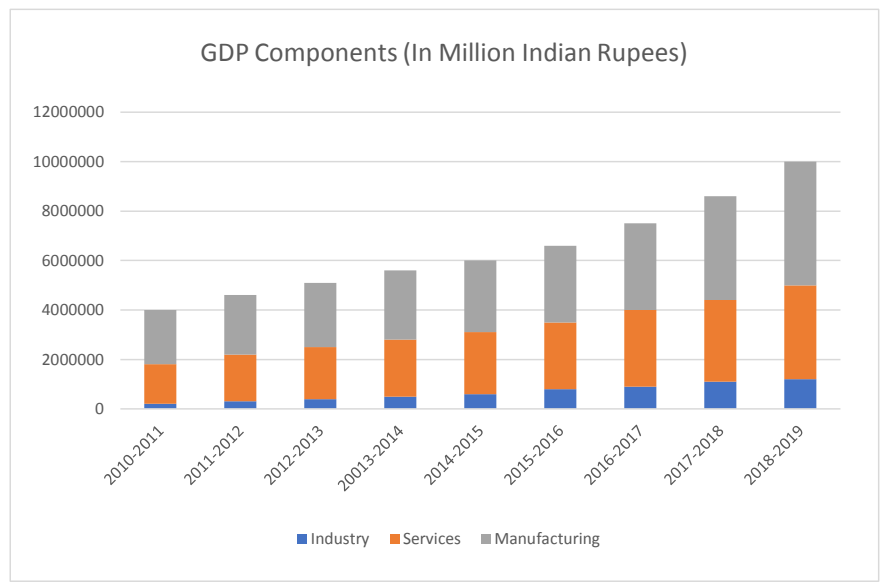

\section{Figure 4: GDP Components in India}

Source: Skill share, https://www.skillshare.net/akshitarora14224/gdp-trends-in-india58117532, accessed on 1/03/2019.

The last decade witnessed a serious shift within the composition of GDP. Share of production, service, and business in GDP has recorded a nonstop increase over the years however when put next, this increase has been highest in the service sector whereas it's been lowest in the production sector.

\footnotetext{
${ }^{21}$ Nilekani, N., Imagining India: Ideas for the new century. International Business 6th edition, New Delhi 2013, p.111-32.
} 
FDI (In Million Indian Rupees)

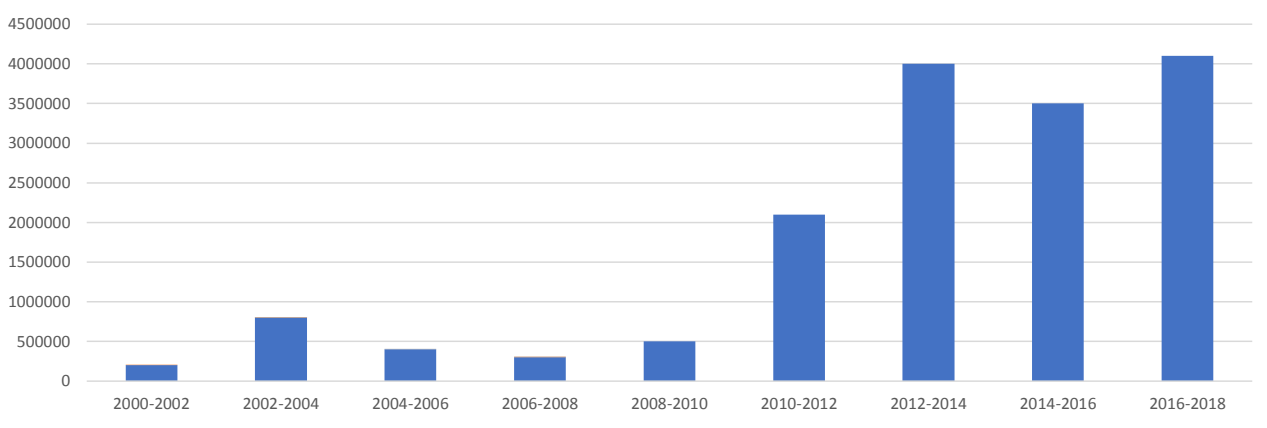

\section{Figure 5: Inward Foreign Direct Investment of India}

Source: Track.in, https://trak.in/tags/business/2012/05/10/fdi-foreign-direct-investment-india2012, accessed on 1/03/2019.

FDI showed an overall increasing trend within the last decade. Within half of the last decade, FDI has remained additional or less stable however 2006-07 recorded a forceful increase ${ }^{22}$, aside from the years 2009-10 \& 2010, this increase in FDI has been highest in the year 200607 wherever it's over doubled over the previous year.

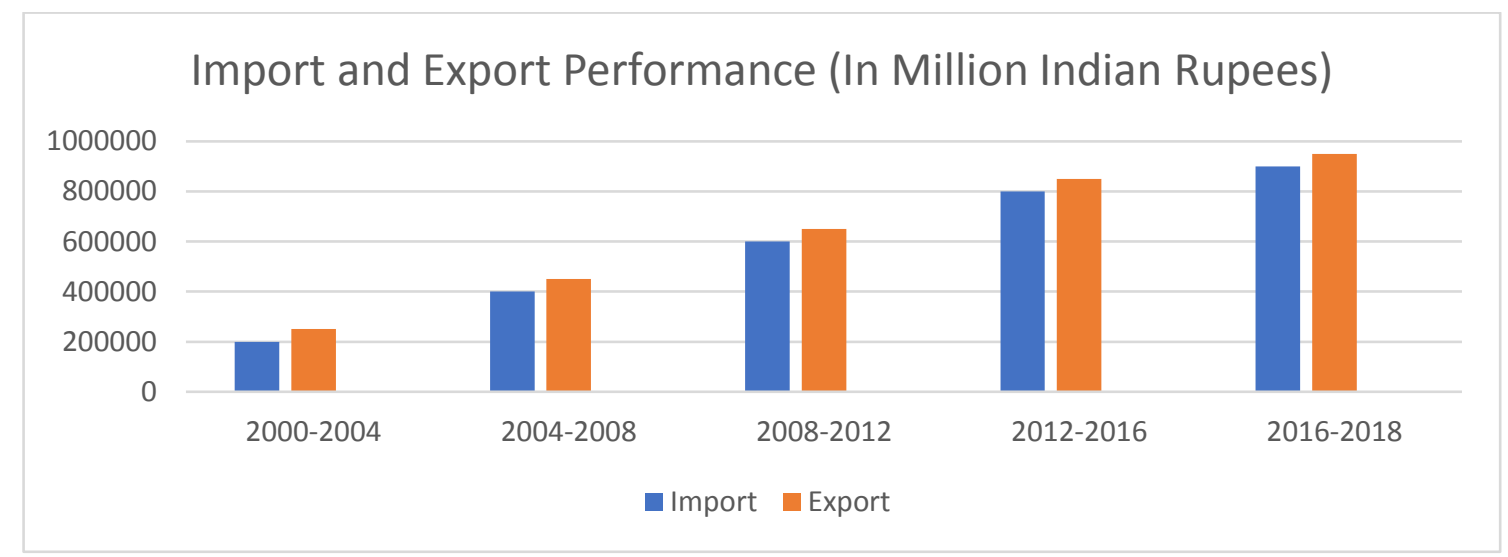

Figure 6: Import and Export Performance of India

Source Track.in, https://trak.in/tags/business/2012/05/10/fdi-foreign-direct-investment-india2012, accessed on 1/03/2019.

Though there has been a rise within the exports also as imports in the last decade, the speed of increase in exports is over that of imports, indicating that our service, production, and industrial sector aren't solely changing into additional and more independent however it's additionally increasing the foreign reserves of the country together with a positive balance of trade. At the time of its independence in 1947, the Asian nation had acquisition rate of 18\%; an investment rate of around 9\% of its GDP; expectancy at birth of thirty-two years; an annual growth rate of 25 percent; and a mean annual rate of growth of GDP of around 3\%; an investment rate of around 30\% of its GDP; expectancy at birth of 63 years; an annual growth

22 in Nilekani, N., Imagining India: Ideas for the new century. International Business 6th edition, New Delhi 2013, p.111-32. 
rate of $15 \%$. GDP growth and rate of growth ${ }^{23}$ is displayed in figure7. A line represents a continuing rate of growth. Table-2 presents annual averages of growth rates and averages over set up periods.

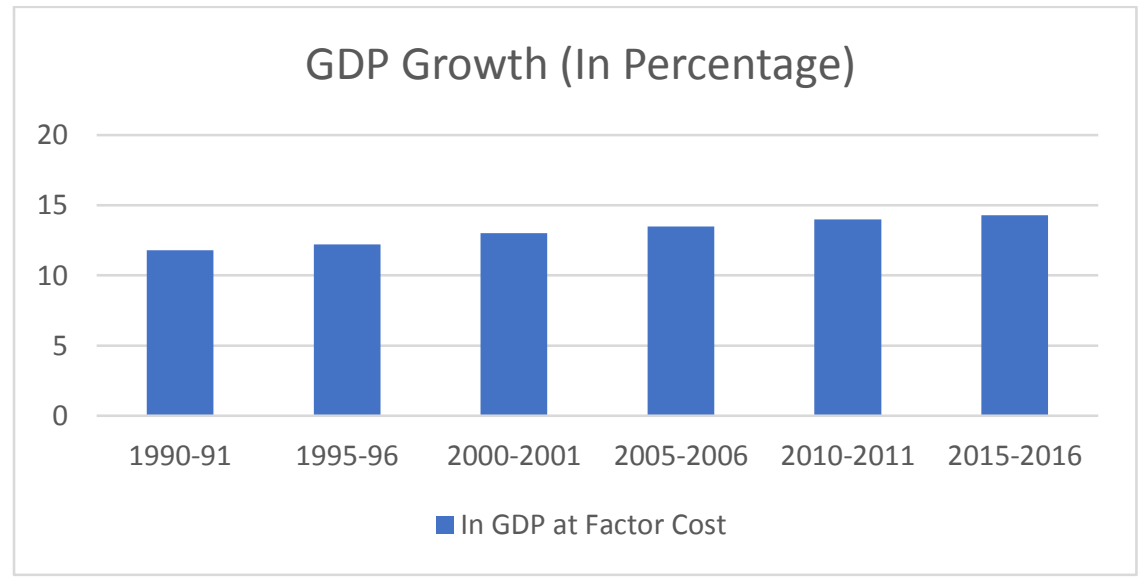

Figure 7: Gross Domestic Product Growth in India in 1990-2016

Source: Reserve Bank of India, Handbook of Statistics on the Indian Economy 2006 (Table 2-old series; base: 1993/4)accessed on 9/03/2019.

The Indian population has doubled since the 1960s, GDP has inflated over multiple since then, With an average annual rate of population growth ${ }^{24}$ of $1.9 \%$. With a mean annual rate of growth of $19 \%$, this ends up in a mean annual growth in per-capita GDP of around $16 \%$. From the late 1970s, the speed of growth exhibits an upward trend, averaging around half-dozen percent for the amount ${ }^{25}$ 1980-2018. To get a basic idea of the absolute numbers involved, Table 2 gives the size of the Indian population, the real GDP (at market prices), and the real GDP per capita (at market prices) ${ }^{26}$. Since the 1960s the Indian population has more than doubled, GDP has increased more than eightfold since then. To answer this question, the purchasing power parity (PPP)corrected national income and per-capita national income data of the World Bank was assembled for 109 countries. ${ }^{27}$

\footnotetext{
${ }^{23}$ Dhiraj. J., Nair. K., Factors Affecting GDP (Manufacturing, Services, Industry): An Indian Perspective, Mumbai 2012, p.141-62.

${ }^{24}$ Kwan. A. C., Cots mitis. J. A., Economic growth and the expanding export sector. International Economic Journal, 1991, p.224-32.

25 Paul. J., Gupta. P., Economic Environment \& Policies for Business. McGraw-Hill, New Delhi 2013, p.100-32.

${ }^{26}$ Singh. G., Paul. J., Foreign direct investments in India. Smart Journal of Management, Gujarat 2014, p.231-42.
} 
Table 2: Population, GDP, and GDP per capita of India at market prices selected years

\begin{tabular}{|l|c|c|c|}
\hline Year & Population (in millions & $\begin{array}{c}\text { GDP (in millions constant } \\
\text { 2000 US\$) }\end{array}$ & $\begin{array}{c}\text { GDP per capita (constant } \\
\text { 2000 US\$) }\end{array}$ \\
\hline 1990 & 435 & 76,283 & 175 \\
\hline 1995 & 487 & 91,054 & 187 \\
\hline 2000 & 548 & 113,606 & 207 \\
\hline 2005 & 613 & 130,913 & 213 \\
\hline 2010 & 687 & 152,621 & 222 \\
\hline 2015 & 765 & 198,167 & 259 \\
\hline
\end{tabular}

Source: : World Development Indicators 2006, World Bank, accessed on 12/03/2019.

From this assembled knowledge set it is clear that not solely has India done higher over time itself, however even compared to others. The rank fluctuated a bit between 1975 and 1982, falling to 93rd and rising once more to the 90th. From 1982 onwards there has been a gradual and monotonic improvement, with India's per-capita gross domestic product, rising to $75^{\text {th }}$ rank in 2004. In 1985, India's corrected gross domestic product was the eighth largest within the world, and by 2004 it was the fourth-largest, with solely the USA, China, and Japan ahead $^{28}$. Despite this rank improvement, India and South Asia normally are still among the poorest regions within the world (see Table 3).

Table 3: GDP per capita of India (constant 2000 US\$), selected comparisons

\begin{tabular}{lrrrrrrr}
\hline & $\mathbf{1 9 8 5}$ & $\mathbf{1 9 9 0}$ & $\mathbf{1 9 9 5}$ & $\mathbf{2 0 0 0}$ & $\mathbf{2 0 0 5}$ & $\mathbf{2 0 1 5}$ & $\mathbf{2 0 1 8}$ \\
\hline India & 187 & 207 & 222 & 316 & 371 & 450 & 538 \\
Sub-Saharan Africa & 485 & 536 & 577 & 520 & 484 & 504 & 537 \\
South Asia & 197 & 220 & 234 & 326 & 377 & 446 & 522 \\
$\quad$ East Asia and Pacific & 145 & 176 & 273 & 481 & 735 & 952 & 1,254 \\
$\quad$ Latin America and the & 2,276 & 2,616 & 3,568 & 3,262 & 3,555 & 3,854 & 3,906 \\
Caribbean & & & & & & & \\
$\quad$ World & 2,843 & 3,316 & 3,974 & 4,555 & 4,748 & 5,237 & 5,516 \\
\hline
\end{tabular}

Source: World Development Indicators 2006, http://documents.worldbank.org/curated/en/918311468316164759/World-developmentindicators-2006, accessed on 11/03/2019.

China has verified that its success depends on its investment in health and education, gender equality and even-handed distribution of wealth ${ }^{29}$. On the other hand, India's low skill rates and poor health outcomes as compared to China's could justify a giant part of the inequality in development between the two countries.

\footnotetext{
${ }^{28}$ Kwan. A. C., Cots mitis. J. A., Economic growth and the expanding export sector. International Economic Journal, 1991, p.521-42.

${ }^{29}$ Dhiraj. J., Nair. K., Factors Affecting GDP (Manufacturing, Services, Industry): An Indian Perspective, Mumbai 2012, p.111-42.
} 


\section{Equality in Income and Employment Share in 2016}

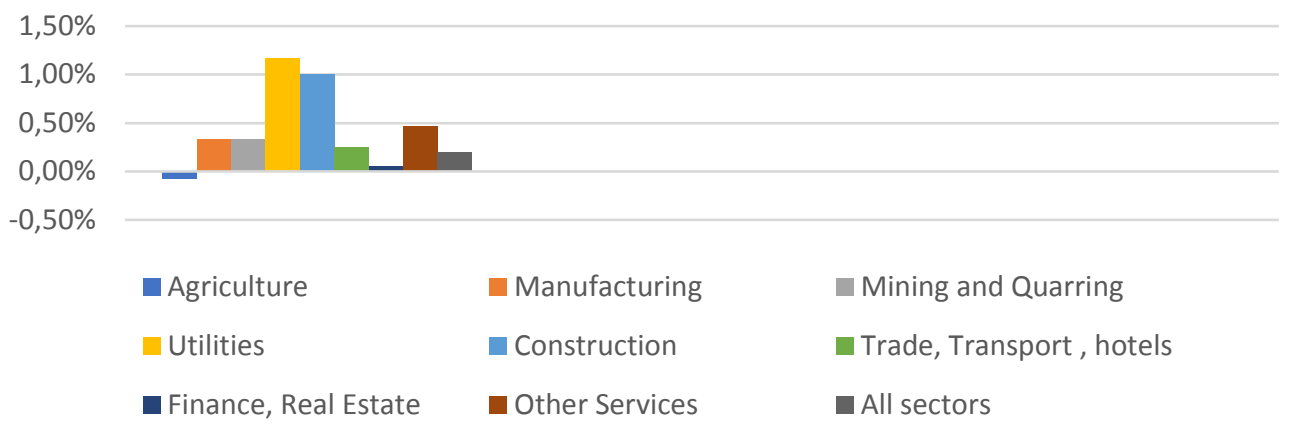

\section{Figure 8: Equality in Income and Employment Share of India}

Source: International Development Economics Associate.

http://www.ideasnetwork.org/blogs/2016/09/recent-growth-in-the-indian-economy accessed on $1 / 03 / 2018$.

The rate of growth of increase used was fraction the speed at that gross domestic product increased throughout this era. The price is negative for agriculture, which signifies a welcome shift of employees far from agriculture whereas not compromising agricultural growth ${ }^{30}$. The only sectors where the price is larger than one are construction and utilities.

\subsubsection{Inclusion:}

During the quarter concluded in September 2015, the typical financial income of an Indian worker was Rs.39,786. This interprets into a mean monthly financial gain of Rs.13,262. Extrapolating these findings from the patron Pyramids survey, we tend to deduce that the typical annual financial gain of Indian households could be very little wanting. A worker might have multiple earning members. Members might earn financial gain within the kind of wages for labor, or within the kind of interest or dividends on capital, or within the kind of rents. Financial gain co-jointly includes profits from family businesses ${ }^{31}$. And, it conjointly includes transfers that households receive from relations operating elsewhere. Though the share is little, financial gain conjointly includes the price of agricultural merchandise created for self-consumption.

Table 4: Proportion of the population living for less than $\$ 1.25$ a day in countries of South Asia (\%)

\begin{tabular}{|l|c|c|c|}
\hline Country & 1981 & 1990 & 2018 \\
\hline Nepal & No data & 77 & 54.7 \\
\hline Bangladesh & 44.2 & 49.9 & 50.5 \\
\hline India & 59.8 & 51.3 & 41.6 \\
\hline Bhutan & 47.4 & 51 & 26.8 \\
\hline Pakistan & 72.9 & 58.5 & 22.6 \\
\hline China & 84.0 & 60.2 & 15.9 \\
\hline Sri Lanka & 31 & 15 & 10.3 \\
\hline Source: World Bank, Development Research Group (2018) & & \\
\hline
\end{tabular}

Source: World Bank, Development Research Group (2018), accessed on 22/03/2019.

30 Yao. S., economic growth, FDI and exports in India. Applied Economics, 2006, p. 121-32.

${ }^{31}$ Khanna. T., China, and India, the power of two. Harvard Business Review, 2009 p.469-72 
Table 4 shows the share of the population living on $\$ 1.25$ daily in countries of South Asia. The reduction in poorness is very important in China followed by the Asian nation ${ }^{32}$. Poorness has magnified in the Asian nation whereas less decrease in poverty is seen within the different countries as well as India.

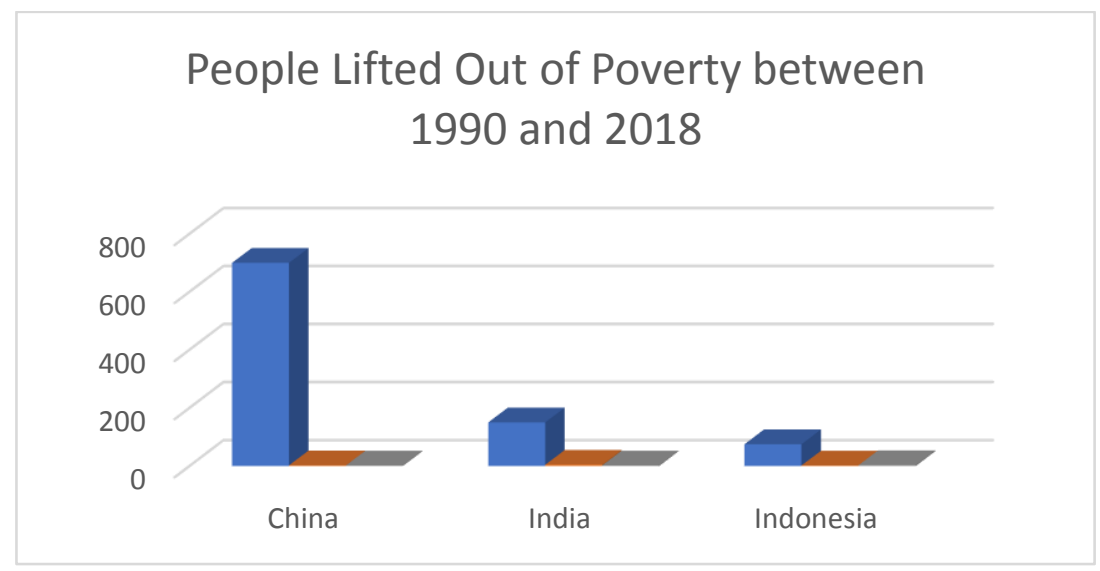

Figure 9: People Lifted Out of Poverty Between 1990 and 2018.

Source: Stored, https://stored.org/on-the-economy/2018/january/income-living-standardschina, accessed on 15/05/2019.

The World Bank's international poverty level of $\$ 1.25$ per day suggests a better range of poor, finding that $42 \%$ percent of the Indian population lives below the poverty level. However, these numbers nearly definitely disappoint of the fact. Nearer to the reality could be a 2007 report by the National Commission on Enterprises within the Unorganized Sector (also referred to as the Arjun Sengupta Commission Report) that calculable 235 million people were able to meet their economic desires. This suggests that the opposite 836 million Indians - or seventyseven percent of the population - had incomes of but $\$ 2$ per day and required government support $^{33}$. In terms of financial gain difference, the Republic of India was near industrialized countries within the early Nineties, however, it is currently turning into more and more unbalanced and nearer to it as seen in China. Specifically, with the market-friendly reforms within the Nineties, the consumption of the young population rose remarkably. In distinction, that of the underside eightieth of the agricultural population declined ${ }^{34}$. Indian billionaires hold over 31 of the value, fourfold more than the worldwide average.

\subsubsection{Intergenerational Equity and Sustainability:}

India's gross domestic savings in 2014 per World Bank knowledge is $30 \%$. What this variety suggests that is if the GDP is Rs100, then the entire savings of the country are Rs31.10.The savings magnitude relation says several things about the nation. A negative magnitude relation is mostly related to countries that are in extreme political distress, are dictators or otherwise failing nations. A negative savings magnitude relation implies that the country is overwhelming as it's producing; this could solely happen through external borrowings or because of economic aid, as within the case of Liberia. In India, this cash goes predominately into gold and assets, thereby inflicting a retardant on the balance of payments because of the gold that needs to be

\footnotetext{
32 Dresher. K., Singh. S., Study of Poverty in India. International Journal of Current Research, 2018, p. 181-92.

${ }^{33}$ Kohli, A., State and Redistributive Development in India. Basingstoke: Palgrave Macmillan, 2012, p. 131-62.

${ }^{34}$ Dresher. K., Singh. S., Study of Poverty in India. International Journal of Current Research, 2018, p. 181-92.
} 
foreign to fulfill this demand, and stoking the sector, supported assets investments that are created in money ${ }^{35}$.

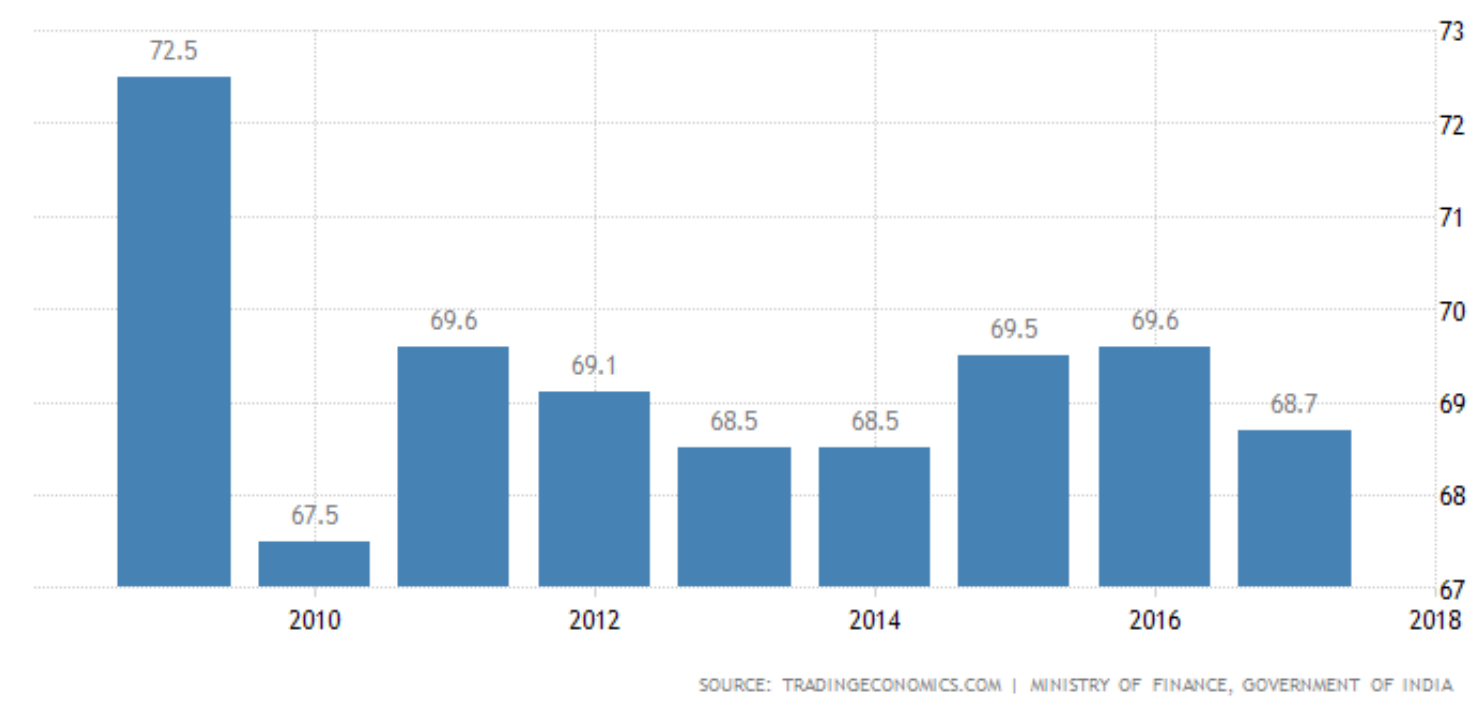

Figure 10: Economic Debt Ratio in the percentage of GDP in India

Source: Trading Economics, https://tradingeconomics.com/india/government-debt-to-gdp, accessed on 12/06/2019.

Varied external debt indicators are showing signs of degradation in debt. The external debt to value quantitative relation stood at $20.5 \%$ as at end-March 2018 , over its level percent at endMarch $2017^{36}$. The quantitative relation of exchange reserves to total debt enhanced to $80.2 \%$ in March this year from $78.5 \%$ However, the debt service quantitative relation declined marginally from 8.5\% in March 2017 to $7.5 \%$ in March 2017. With world interest rates rising following the America federation raising its policy rates, the debt service quantitative relation may rise ${ }^{37}$. In 2017 Republic of India debt was $\$ 27,251$ million, has enhanced $\$ 618.118$ million since 2016. This quantity implies that the debt in 2018 reached $69.79 \%$ of the Republic of India value, a 0.05 mathematical notation fall from 2017 , once it was $69.84 \%$ of GDP. If we tend to check the tables we can see the evolution of the Republic of India debt. It's up since 2007 in world debt terms, once it was $\$ 13,106$ million though it's fallen as a proportion of value, once it amounted to $74.54 \%$. India recorded a government debt cherish $68.70 \%$ of the country's Gross Domestic Product in 2017. Government Debt to value in the Republic of India averaged 73.24 $\%$ from 1991 till $2017^{38}$.

\footnotetext{
${ }^{35}$ Alcoser. J., Monitors opportunities in India. Harvard Business School Case, 2008, p. 281-92.

${ }^{36}$ Alcoser. J., Monitors opportunities in India. Harvard Business School Case, 2008, p.281-92.

${ }^{37}$ Christina. C., The Impacts of High Growing Government Debt on Economic Growth: An Empirical Investigation of the Euro Area, ECB Working paper series No. 1237, 2010, p.781-88.

${ }^{38}$ Alcoser. J., Monitors opportunities in India. Harvard Business School Case, 2008, p.281-92
} 


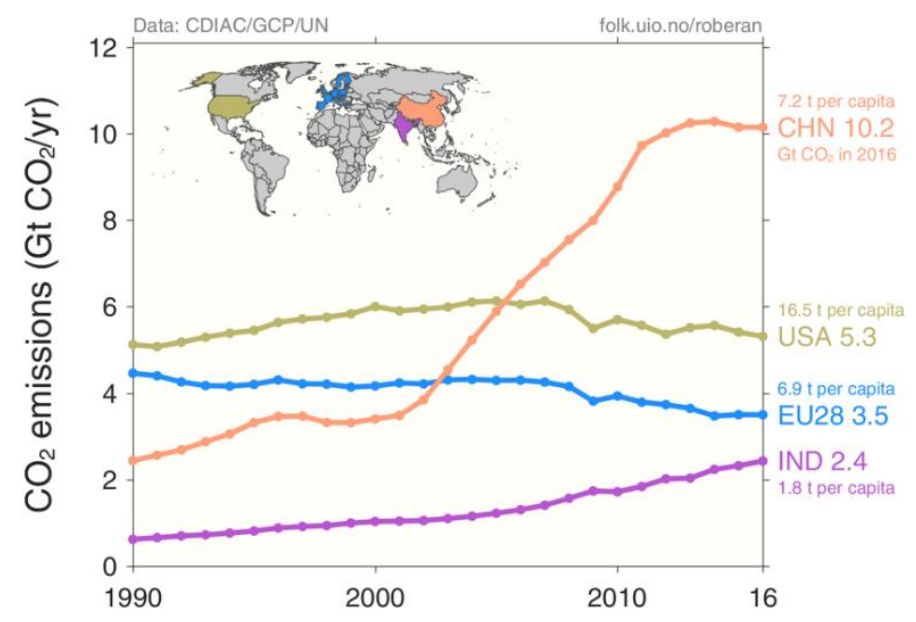

Figure 11: CO2 Emissions

Source: Visually, www.carbon.org/guest-post-why-indias-co2-emissions-in-2017. Accessed on 27/03/2019.

India these days as well as reducing the emission intensity of gross domestic product, sound non-fossil fuel energy sources and making further carbon sink to fulfill its commitment towards the international fight against global climate change. India is well reducing the emission intensity of gross domestic product, sound non-fossil fuel energy sources and making further carbon sink. India, together with partner countries, is building a global star alliance that will contribute to the transition towards renewable energy globally. Carbon dioxide emissions that cause heating are seeming to rise by the maximum amount like $2.7 \%$ in 2018 . This development comes when 3 years of very little or no growth and is similar to the last decade ending 2018, once emissions grew by over $3 \%$ once a year. That peak may well be surpassed if coal use continues to rise in China and the Asian nation ${ }^{39}$.

${ }^{39}$ Adam. P., Become. W., Economic growth, industrial structure, and technical efficiency: empirical evidence from Ghana, Senegal, and Morocco on the causal dynamics, 2012, p.81-92 


\subsection{Competitiveness of China}

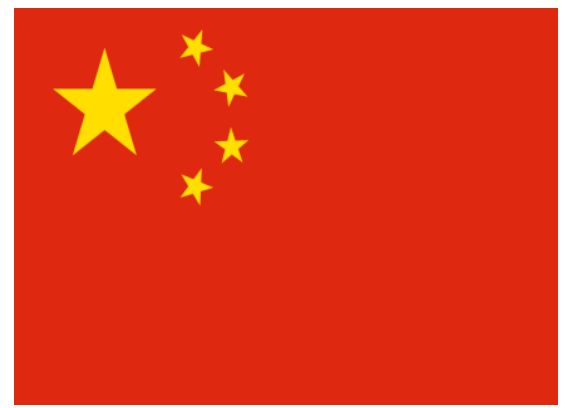

\section{Figure 12: Flag of China}

Source: Britannica, https://www.britannica.com/topic/flag-of-China, accessed on 28/03/2019.

China's rise over the past century is an example of the impact of the rising economy on world markets. Here are a variety of the key charts that facilitate justify China's rise:

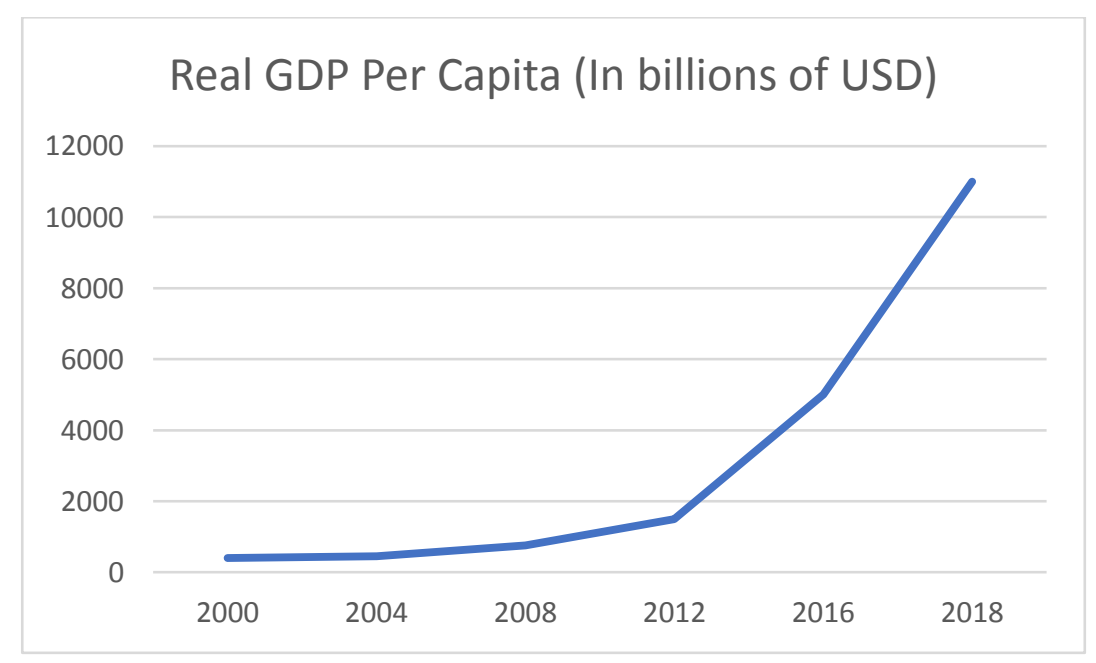

\section{Figure 13: Real GDP Per Capita of China}

Source: MGM Research, https://mgmresearch.com/china-vs-united-states-a-gdp-comparison, accessed on 28/03/2019.

The first 20 years following the establishment of the People's Republic of China in 1949 was marked by periods of right smart growth in per capita price growth ${ }^{40}$. It set the groundwork for future growth by introducing reforms that allowed farmers to sell their product in native markets and commenced the shift from collective farming to the organization's responsibility system ${ }^{41}$. The Chinese economy full-fledged astonishing growth inside the last few decades that catapulted the country to become the world's second-largest economy. In 1978-when China started the program of economic reforms - the country stratified 9th in the nominal gross domestic product (GDP) with USD 214 billion; whereas the secondary sector still accounted for

\footnotetext{
${ }^{40}$ Brandt., Loren., Deben. Ma., Rawski., From Divergence to Convergence: Re-evaluating the History Behind China's Economic Boom. Economic History Working Papers 41660, London School of Economics and Politics 2012, p.3152

41 Bowles. P., Re-balancing China's growth: Some unsettled questions. Canadian Journal of Development Studies, 2012, p.41-62
} 
a sizeable $45 \%$ of the country's total output ${ }^{42}$. Given the solid monetary position of the government, the stimulation measures didn't derail China's public finances. China came out of the financial crisis due to gross domestic product growing on top, less inflation and an efficient monetary position. However, the policies implemented throughout the crisis to foster process exacerbated the country's political economy imbalances. Considerably, the stimulation program bolstered investment, whereas households' consumption remained relatively low ${ }^{43}$. Therefore to tackle, these imbalances, the new administration of the President has adopted economic measures that are focused toward promoting a balanced economic model.

\subsubsection{Growth and Labour Development:}

Chinese GDP had a completely cheap rate since the worldwide cash crisis, amid the intense trade dispute with America, hence weakening domestic demand and creating borrowings by native governments. Considering full 2018, the economy enlarged $6 \%$, the weakest pace since 1990. Previously, China's data point bureau revised down the country's gross domestic product growth for 2017 to $6.8 \%$. The Chinese government set a 2018 growth target of around $5 \%$. For 2017, the Chinese data point bureau revised down ${ }^{44}$ the country's gross domestic product growth to $6.8 \%$ from $9 \%$. On a quarter-on-quarter basis, the gross domestic product advanced $5 \%$, compared to a $1.6 \%$ growth among the previous quantity and in line with market estimates. It completely was the weakest pace of quarterly growth in three quarters. The services sector inflated $7 \%$, slower than $8.2 \%$ growth in 2017. At the identical time, mounted quality investment went up 5.9\%, in 2017. personal investment went up 8.7\%, 2.7 proportion points faster than in 2017. Total trade grew by $9.7 \%$ in 2017 . Exports inflated by $7.1 \%$, whereas imports went up at a faster $12.9 \%$.

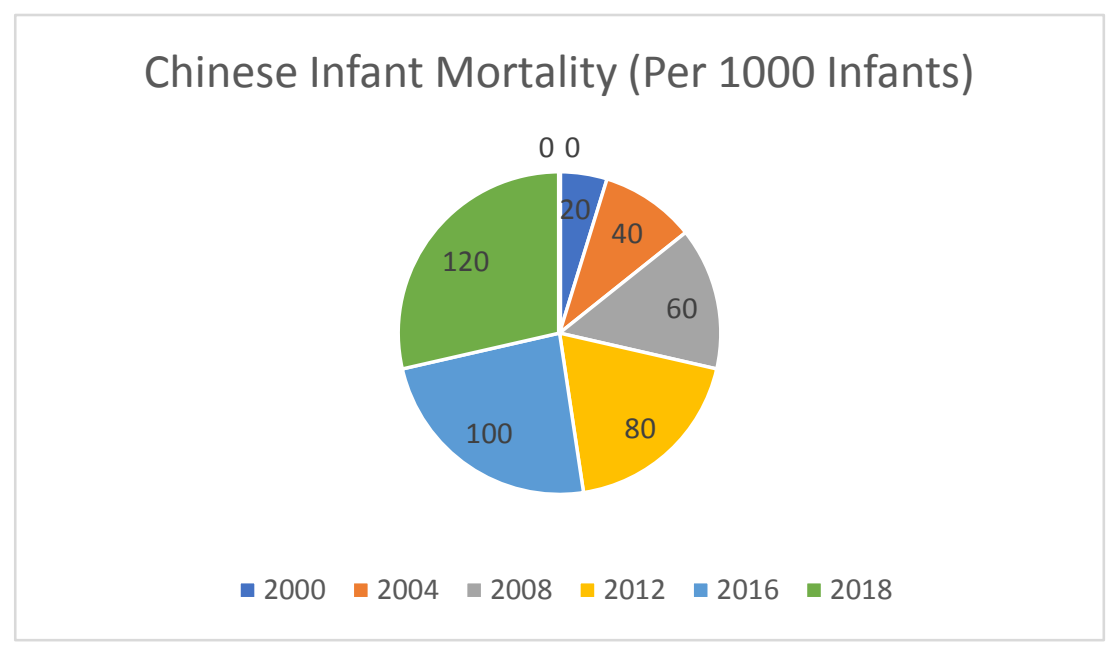

Figure 14: Chinese Infant Mortality

Source: Statista, https://www.statista.com/mortality-in-china, accessed on 15/05/2019.

\footnotetext{
42 Bowles. P., Re-balancing China's growth: Some unsettled questions. Canadian Journal of Development Studies, 2012, p.41-62
} 


\subsubsection{Inclusion:}

There are some ways to live financial gain and the price of living. During this post, we'll examine some of them to research financial gain and living standards across China. A common criterion for gauging the living customary of a nation is real per capita gross domestic product (GDP). Real per capita value is the average quantity of products and services made per person in an exceedingly nation in a given year at constant costs ${ }^{45}$.

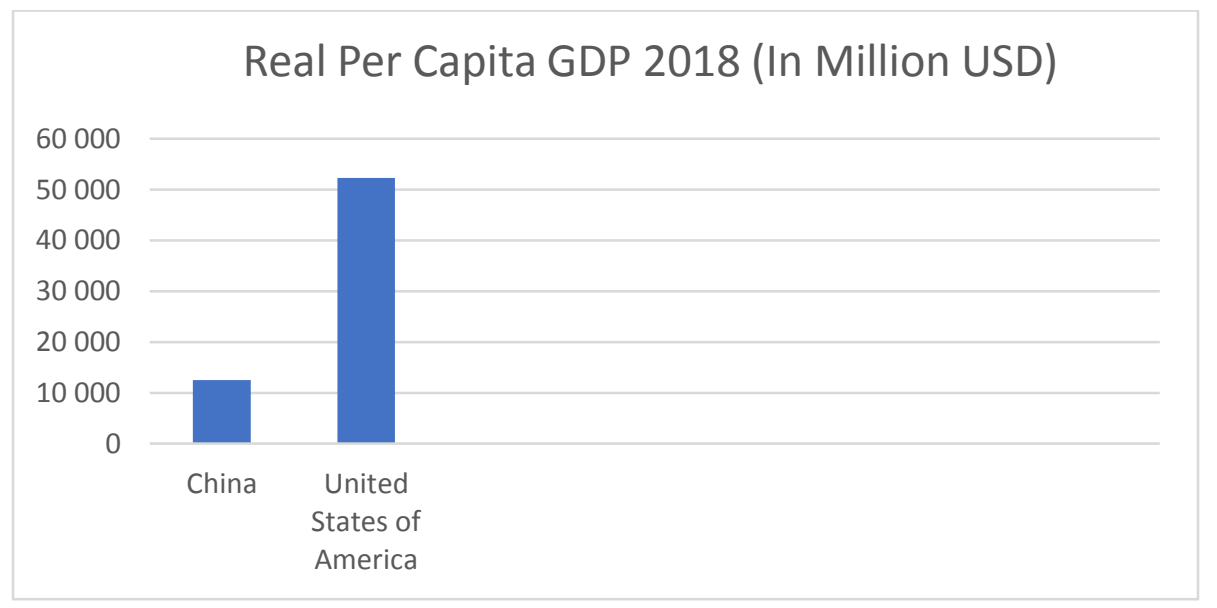

\section{Figure 15: Real GDP Per Capita of China in 2018 (In Million USD)}

Source: stored, https://stored.org/on-the-economy/2018/january/income-living-standardschina, accessed on 8/03/2019.

For the planet as a full, average real per capita value was $\$ 20,055.65$. The massive distinction between the common and therefore the median financial gain implies that world income is targeted in an exceedingly few made countries. However, since life relies on the common financial gain of every nation, it doesn't capture the difference in living standards among a nation. The figure shows that China's average real per capita financial gain is $\$ 12,472.51$, that is in line with the planet median financial gain however way below the world average ${ }^{46}$. China achieved tremendous progress inside the reduction of every gain and human poorness between 1978 and 1985. The shift to developing ways in favor of the coastal areas whereas not enough compensation for poor western areas, combined with short funds contributed to the stagnation of poorness reduction. After 1993, notably in 1994, once the good anti-poverty program was formally established, the Chinese government's revived commitment to poorness reduction began to point out some results. By the beginning of 1997, the proportion of the population living below the national income fell to fifty-eight million. China's experiences in poorness reduction tell the next lessons ${ }^{47}$. Political commitment to poorness reduction ought to be combined with financial commitment within the least times. The government should endorse education-for-all and health-for-all policies. The incidence of poorness depends on the choice of private financial gain. The earth Bank report in 1992 China: ways for Reducing poorness inside the 1990s suggests that fewer than 100 million Chinese ${ }^{48}$ lived in the economic condition in 1993, declining from 270 million in 1978.

\footnotetext{
${ }^{45}$ Chen. S., Wang. Y., 2001. China's growth and poverty reduction: recent trends between 2000 and 2018. WBIPIDS Seminar on Strengthening Poverty Data Collection and Analysis held in Manila, Philippines, 2001, p.126-52

${ }^{46}$ Own Elaboration

47, Khanna. T., China, and India, the power of two. Harvard Business Review, 2009, p.469-72.

48 Own Elaboration
} 


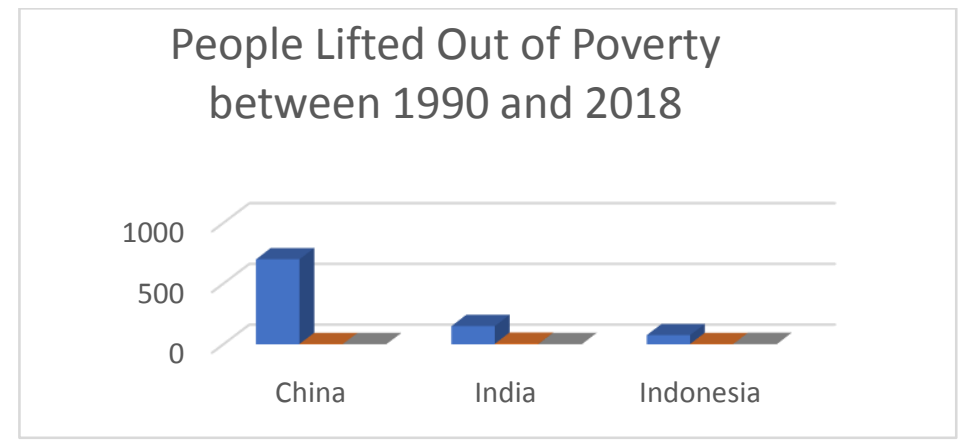

Figure 16: People Lifted Out of Poverty Between 1990 and 2018.

Source: https://stlofed.org/on-the-economy/2018/january/income-living-standards-china, accessed on 8/03/2019.

\subsubsection{Intergenerational Equity and sustainability:}

A key plan of China's latest was the scrapping of the remaining rate of interest caps on short deposits. The easement of the rate of interest regime ought to support China's ambitions to induce the yuan other to the International Financial Fund's pool of international reserve currencies $^{49}$. However, the move conjointly has implications for the way China's transformation off from an export and investment economy to a consumption-led economy plays out ${ }^{50}$.

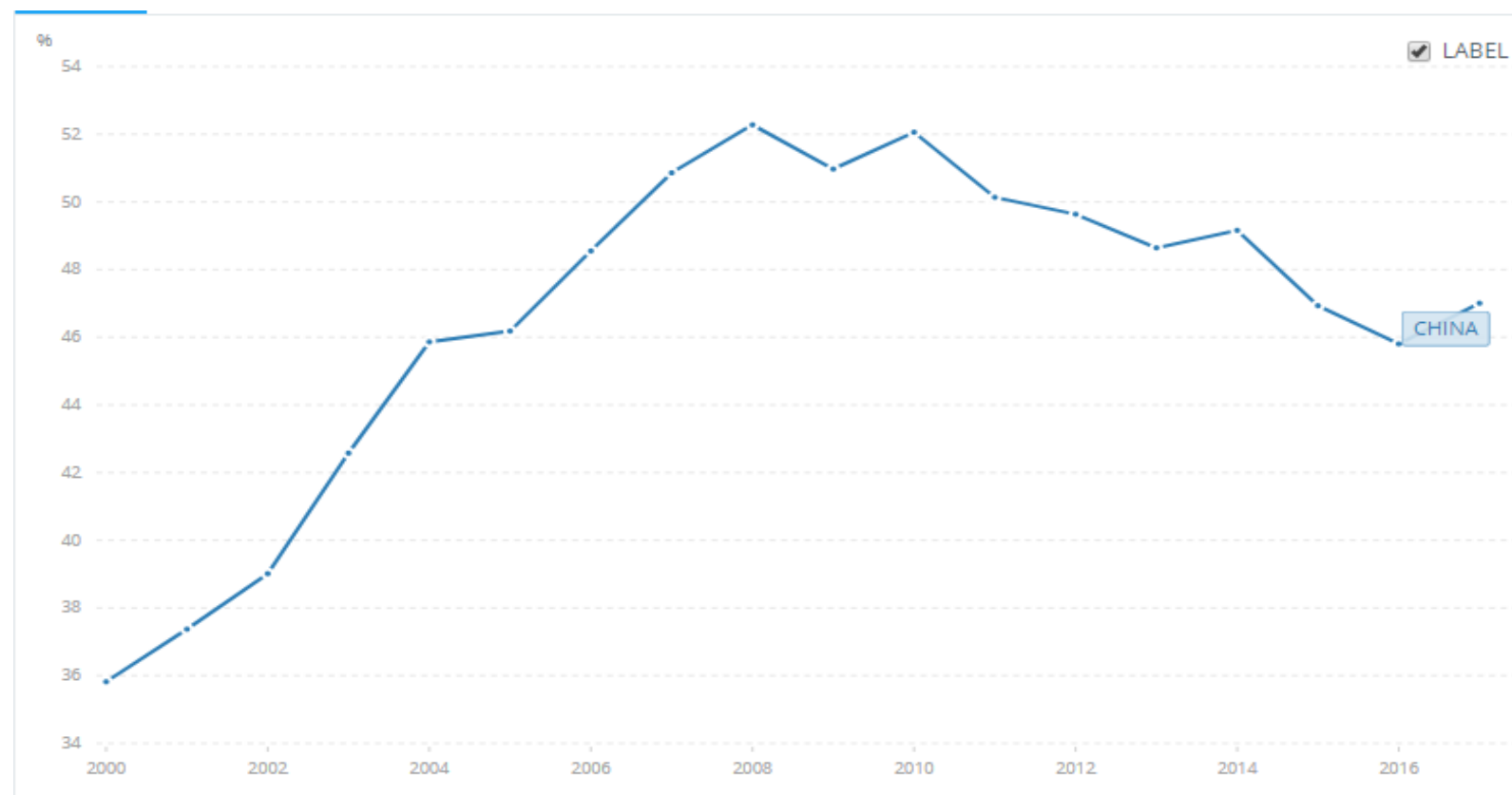

\section{Figure 17: Adjusted Net Saving of China}

Source: The world bank, https://data.worldbank/GNS.ICTR.ZS, accessed on 22/03/2019.

No single theory or model can seemingly give a straightforward rationalization to those patterns of high Chinese saving. whereas the proof seems mixed to the proposition that China's high saving rate is mainly a perform of subsidies and distortions, a number of the structural forces might not have received comfortable attention. China's \$34 trillion pile of public and

${ }^{49}$ Kraal. A., Household Saving in China. The World Bank Economic Review, 2000, p.06-12 
personal debt is Associate in Nursing explosive threat to the world economy. The challenge is a way to wean the country off its debt drip while not deepening Associate in Nursing economic delay. Chia outpaced the U.K. and U.S. in terms of growth within the decade before the monetary crisis ${ }^{51}$. The government is targeting cuts in its budget; and sweeping rules were introduced to tackle shadow banking, a $\$ 10$ trillion network of unregulated disposal and risky investment merchandise.

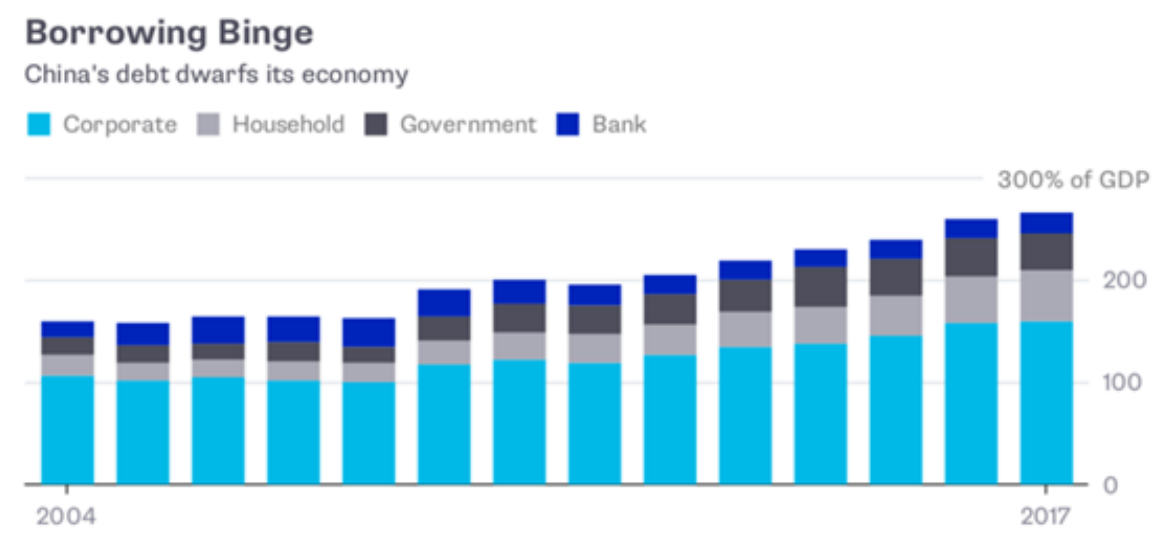

Figure 18: Debt ratio of China

Source: National Bank of Belgium

https://www.nbb.be/doc/ts/enterprise/speeches/presentations/presentationwp271.pdf, accessed on 26/03/2019.

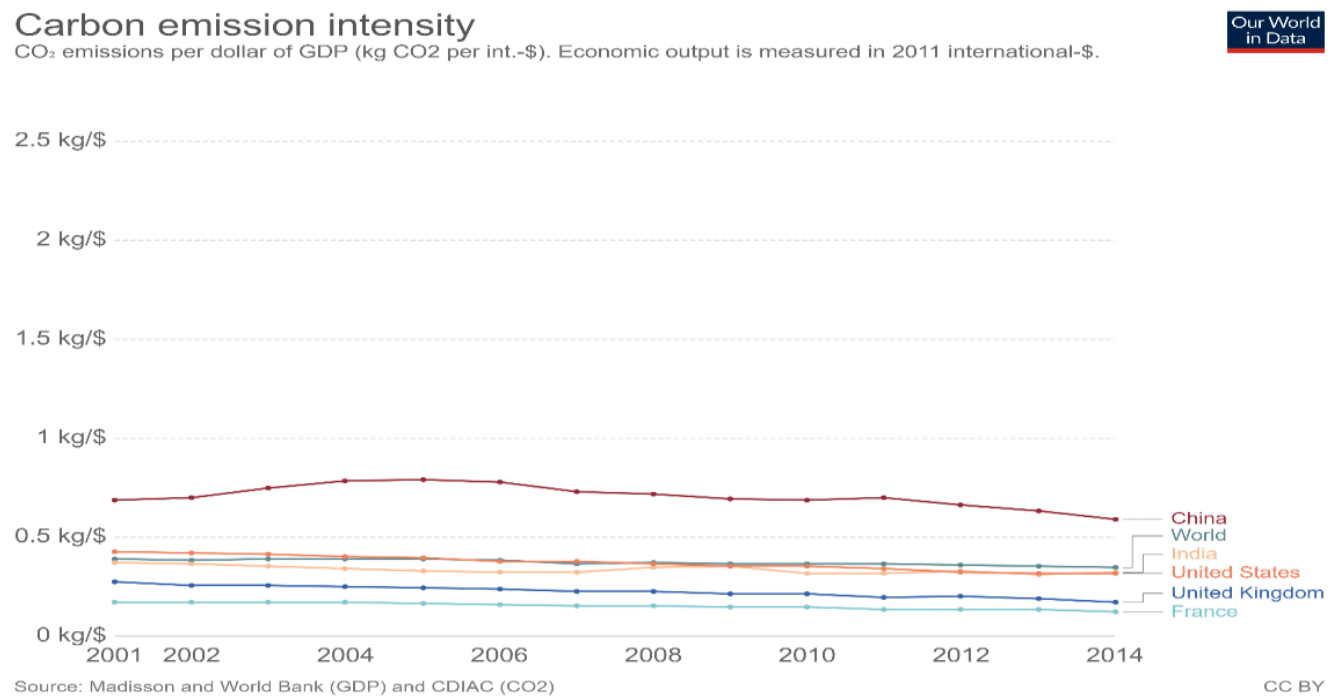

Figure 19: Carbon Emission Intensity

Source: carbonbrief.org, https://www.carbonbrief.org/guest-post-why-indias-co2-emissions-grewstrongly-in-2017 accessed on 1/04/2019

The link between carbonic acid gas (CO2) emissions and prosperity (GDP) has created international temperature change a factious issue to tackle. Carbon intensity measures the amount of dioxide emitted per unit of value and is measured in kgCO2/GDP each year. To reconcile increasing material well-being with a smaller environmental impact we'd like carbon intensity to fall.

${ }^{51}$ Kraal. A., Household Saving in China. The World Bank Economic Review, 2000, p.06-12 


\subsection{Comparison of India and China based on Hard Data:}

- GDP

Table 5: GDP in 2018 (Trillion United States Dollar)

\begin{tabular}{|l|l|l|}
\hline Ranking $^{52}$ & Country & GDP in 2018 (Trillion \$) \\
\hline 1 & US & 20.5 \\
\hline 2 & CHINA & $\mathbf{1 3 . 6}$ \\
\hline 3 & JAPAN & 5.0 \\
\hline 4 & GERMANY & 4.0 \\
\hline 5 & UK & 2.8 \\
\hline 6 & FRANCE & 2.8 \\
\hline 7 & INDIA & $\mathbf{2 . 7}$ \\
\hline 8 & BRAZIL & 2.1 \\
\hline 9 & CANADA & 1.9 \\
\hline 10 & RUSSIA & 1.7 \\
\hline 11 & SOUTH KOREA & 1.7 \\
\hline 12 & ITALY & 1.6 \\
\hline 13 & SPAIN & 1.4 \\
\hline
\end{tabular}

Source: Forbes, https://www.forbes.com/sites/salvatorebabones/india-will-outgrow-china-in2018-but-must-invest-in-next-generation-value-chains, accessed on 18/09/2019.

As mentioned in table-5, the United States of America is the leader with a GDP of 20.5 trillion Dollars. GDP is an associate correct indication of an economy's size, whereas gross domestic product per capita includes a correlation with the trend in living standards over time, and so the gross domestic product rate of growth could also be the sole best indicator of the process. Chinese GDP ranks second in the world with a GDP of 13.6 trillion U.S dollars. Hence china leads India in terms of GDP as Chinese GDP is almost six times as that of the GDP of India.

- Labour Market:

Table 6: Percentage increase in Labour Market (2010-2018)

\begin{tabular}{|l|l|l|}
\hline Ranking $^{53}$ & Country & $\begin{array}{l}\text { Percentage increase in } \\
\text { Labor Market (2010-2018) }\end{array}$ \\
\hline $\mathbf{1}$ & China & $\mathbf{1 4}$ \\
\hline $\mathbf{2}$ & Vietnam & 6 \\
\hline $\mathbf{3}$ & India & $\mathbf{5}$ \\
\hline $\mathbf{4}$ & Indonesia & 3.5 \\
\hline 5 & Malaysia & 3.2 \\
\hline 6 & Sri-Lanka & 3.1 \\
\hline
\end{tabular}

Source: Conference Board, https://www.conference-board.org/ilcprogram, accessed on 17/09/2019.

\footnotetext{
${ }^{52} \mathrm{https}$ :/www.forbes.com/sites/salvatorebabones/2018/01/02/india-will-outgrow-china-in-2018-but-must-invest-innext-generation-value-chains/\#5c1275d44d87 accessed on 18/09/2019

53 https://www.conference-board.org/ilcprogram/index.cfm?id=38270 accessed on 17/09/2019.
} 
The percentage increase in the labor market between 2010-2018 in china was 14\% whereas that of India was $5 \%$. Hence china has more skilled manpower as compared to that of India.

\section{- Employment:}

Table 7: Employment in India and China in Millions (2010-2018)

\begin{tabular}{|l|l|l|}
\hline Year $^{54}$ & $\begin{array}{l}\text { Total Employed in China } \\
\text { (Millions) }\end{array}$ & $\begin{array}{l}\text { Total Employed in India } \\
\text { (Millions) }\end{array}$ \\
\hline 2010 & 600 & 300 \\
\hline 2011 & 633 & 330 \\
\hline 2012 & 655 & 365 \\
\hline 2013 & 676 & 382 \\
\hline 2014 & 774 & 412 \\
\hline 2015 & 726 & 444 \\
\hline 2016 & 753 & 468 \\
\hline 2017 & 777 & 486 \\
\hline 2018 & 800 & 500 \\
\hline
\end{tabular}

Source: Rabobank, https://economics.rabobank.com/publications/2017/march/unleashingchina-indias-growth-potential-productivity-growth, accessed on 17/09/2019

Table-7 showcases an ever-increasing trend of the rapid increase in employment in China from 600 million in 2010 to 800 million in 2018. In case if India's employment has increased steadily from 300 million in 2010 to 500 million in 2018. Fewer jobs within the economy (assuming the population is growing) can lead to a higher rate of unemployment even though the economy is working at potential, which can't be reduced through ancient strategies of job creation. Thus conclusion from the table-7 is that the government of India needs to introduce new reforms to boost the manufacturing sector and education system to reduce the skill gap.

- Median Household Income:

Table 8: Median Household Income Rank of India and China

\begin{tabular}{|l|l|l|}
\hline Rank $^{55}$ & Country & $\begin{array}{l}\text { Median Household Income } \\
\text { (US Dollars) }\end{array}$ \\
\hline 1 & Norway & 51,489 \\
\hline 2 & Sweden & 50,514 \\
\hline 3 & Luxembourg & 52,493 \\
\hline 42 & Russia & 11,724 \\
\hline 59 & Brazil & 7,522 \\
\hline $\mathbf{6 7}$ & China & $\mathbf{6 , 1 8 0}$ \\
\hline 79 & South Africa & 5,217 \\
\hline $\mathbf{9 9}$ & India & $\mathbf{3 , 1 6 8}$ \\
\hline 129 & Mali & 1,983 \\
\hline 130 & Burundi & 673 \\
\hline
\end{tabular}

Source: Bulletin board, https://www.rba.gov.au/publications/bulletin, accessed on 18/09/2019

\footnotetext{
${ }^{54}$ https://economics.rabobank.com/publications/2017/march/unleashing-china-indias-growth-potential-productivitygrowth/accessed on 17/09/2019

${ }^{55}$ https://www.rba.gov.au/publications/bulletin/2016/sep/4.html, accessed on 18/09/2019
} 
According to the table-8 Median Household Income of China is 6180 U.S dollars, whereas that of India is $3168 \mathrm{U} . S$ dollars. This indicates that the rural-urban gap in the pay scale in India is much wider than that of China. The Indian government needs to introduce economic reforms that can boost the industrial sector, education, and transportation sector to tackle the rural-urban gap in pay scale.

- Income Gini:

Table 9: Income Gini of India and China (2000 and 2018)

\begin{tabular}{|l|l|l|}
\hline Country $^{56}$ & Income Gini in 2000 & Income Gini in 2018 \\
\hline Korea & 32 & 30 \\
\hline Nepal & 38 & 36 \\
\hline Philippines & 43 & 41 \\
\hline Japan & 26 & 31 \\
\hline Vietnam & 35 & 39 \\
\hline Indonesia & 32 & 38 \\
\hline Bangladesh & 33 & 42 \\
\hline India & $\mathbf{5 5}$ & $\mathbf{4 4}$ \\
\hline Papua New Guinea & 40 & 52 \\
\hline China & $\mathbf{5 1}$ & $\mathbf{3 1}$ \\
\hline
\end{tabular}

Source: The Diplomat, https:/thediplomat.com/2015/11/the-economic-risks-of-indias-wealthinequality, accessed on 15/09/2019

Table-9 indicates Income Gini of India and China in 2000 and 2018. In 2000 Income Gini of China was 51\% and in 2018 was 31\%. Whereas Income Gini in India was 55\% in 2000 and $44 \%$ in 2018. The decline in Income Gini of China is much greater as compared to that of India. Hence it can be concluded that in the case of Income Gini, The rising influence of the rich and stagnant incomes of the poor and sophistication have a causative result on crises, and thus directly hurt short and long growth. Particularly, In addition to poignant growth drivers, income inequality could result in poor public policy selections, it'll end in a backlash against growthenhancing economic easement and fuel proponent pressures against the process and marketoriented reforms.

- Poverty Rate:

Table 10: Poverty rate of India and China (1981-2018)

\begin{tabular}{|l|l|l|}
\hline Poverty Rate & China (\%) & India (\%) \\
\hline 1981 & 82 & 60 \\
\hline 1990 & 60 & 52 \\
\hline 2010 & 35 & 37 \\
\hline 2018 & 11 & 30 \\
\hline
\end{tabular}

Source: Live mint, https://www.livemint.com/Opinion/India-Pakistan-and-Bangladesh-70years-after-the-British, accessed on 15/09/2019.

\footnotetext{
${ }^{56} \mathrm{https}: / /$ thediplomat.com/2015/11/the-economic-risks-of-indias-wealth-inequality, accessed on 15/09/2019

${ }^{57}$ https://www.livemint.com/Opinion/cHhfx1 Inclvpu7F3FrFY1N/India-Pakistan-and-Bangladesh-70-years-after-the-

British-le.html accessed on 15/09/2019.
} 
Poverty Rate in China has declined from $82 \%$ in 1981 to only $11 \%$ in 2018 . Whereas in India the poverty rate has declined from $60 \%$ to $30 \%$. The rapid rate in poverty decline is mainly due to the increase in the economic competitiveness of both nations. China leads India in terms of percentage poverty reduction. nation's population living below the personal income has very little cash to pay, there's less demand for several products that may well be the case. That adversely affects the supply-side of the economic equation, which implies less cash paid to others to supply and distribute.

\section{- Public Dept:}

Table 11: Public Debt of India and China (2018)

\begin{tabular}{|l|l|}
\hline Country & Debt (2018) \\
\hline Hungary & 79.1 \\
\hline Croatia & 66.3 \\
\hline Brazil & 65.8 \\
\hline India & $\mathbf{6 0 . 5}$ \\
\hline Malaysia & 56.6 \\
\hline Mexico & 48 \\
\hline South Africa & 47.9 \\
\hline China & $\mathbf{4 0 . 7}$ \\
\hline Turkey & 33.6 \\
\hline
\end{tabular}

Source: Economist, https://www.economist.com/briefing/2007/02/01/india-on-fire, accessed on $12 / 09 / 2019$.

Public debt in India is $60.5 \%$ whereas that of China is $40.7 \%$ in 2018 . When the debt is approaching a critical level, investors usually start demanding a higher interest rate, they want more return for the higher risk. The country may receive a lower S\&P rating if it keeps spending, then its bonds. This showcase how likely it is the country will default on its debt. It becomes more expensive for a country to refinance its existing debt as interest rates rise.

\section{- Debt Ratio:}

Table 12: Debt Ratio of India and China (2010-2018)

\begin{tabular}{|l|l|l|}
\hline Year & India (Debt to GDP) & Ch \\
\hline 2010 & 74 & 34.5 \\
\hline 2011 & 74.5 & 31.6 \\
\hline 2012 & 72.5 & 36.9 \\
\hline 2013 & 67.5 & 35.1 \\
\hline 2014 & 69.6 & 35.3 \\
\hline 2015 & 69.1 & 36.9 \\
\hline 2016 & 68 & 39.5 \\
\hline 2017 & 68.3 & 41.1 \\
\hline 2018 & 69 & 43.9 \\
\hline
\end{tabular}

Source:Jagran-josh,https://www.jagranjosh.com/general-knowledge/13-parameters-tocompare-india-and-china accessed on 10/09/2019

\footnotetext{
$58 \mathrm{https}: / / w w w . e c o n o m i s t . c o m /$ briefing/2007/02/01/india-on-fire, accessed on 12/09/2019.

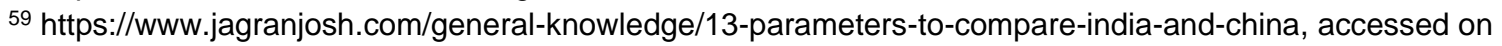
$10 / 09 / 2019$
} 
Table-12 indicates the Debt to GDP ratio of India and China from 2010 to 2018. In the year 2010, the Debt to GDP ratio in India was 74 which reduced to 69 in 2018. In China Debt to GDP ratio was 34.5 in 2010 which increased to 43.9 in 2018 . Although the debt to GDP ratio has decreased significantly in India it is still much higher than the debt to GDP ratio of China. The depth ratio proportion is the proportion of a nation's public depth to its total national output (GDP). On the off chance that a nation is unfit to pay the debt, it could cause a budgetary panic in the local and universal markets. The higher the depth to GDP proportion, the more uncertain the nation will pay back its depth and the higher its danger of default.

- Carbon Intensity of GDP:

Table 13: Carbon Intensity of GDP India and China (2010-2018)

\begin{tabular}{|l|l|}
\hline Country60 & Co2 Emissions (In Trillion-Dollar Value) \\
\hline United States & 5.1 \\
\hline Europe & 3.2 \\
\hline China & $\mathbf{8 . 4}$ \\
\hline India & $\mathbf{2 . 5}$ \\
\hline
\end{tabular}

Source: Jagran-josh, https://www.jagranjosh.com/general-knowledge/13-parameters-tocompare-india-and-china, accessed on 10/09/2019.

Table-13 indicates that Carbon Intensity of GDP is 8.4 Trillion U.S Dollars whereas that of India is only 2.5 Trillion U.S Dollars. The link between carbonic acid gas (CO2) emissions and prosperity (GDP) has created international temperature change a factious issue to tackle. Inorder to maintain development and economic progress it is important to control and reduce Carbon Dioxide emissions. India has done particularly well to keep the Carbon Dioxide emission in control whereas China needs to focus more on reducing emissions to reducing Carbon Dioxide emission impact on Gross Domestic Product and Government wealth.

\footnotetext{
60 Jagran-josh, https://www.jagranjosh.com/general-knowledge/13-parameters-to-compare-india-and-china, accessed on 10/09/2019
} 


\section{Conclusion:}

Indian GDP (purchasing power parity) is $\$ 9.128$ trillion in 2019, $\$ 8.452$ trillion in 2018 and $\$ 8.652$ trillion in 2017 in dollars. Whereas china's GDP (purchasing power parity) is $\$ 23.12$ trillion in 2019, $\$ 21.66$ trillion in 2018 and $\$ 20.3$ trillion in 2017. Chinese purchasing power parity is more than double as compared to that of India. GDP - the real growth rate of India is $6.1 \%$ in $2019,7.1 \%$ in 2018 and $7 \%$ in 2017 . whereas that of china is $6.8 \%$ in $2019,6.3 \%$ in $2018,6.2 \%$ in 2017. The growth of India in 2017 and 2018 was greater than that of China, however, China overtook India in terms of growth in 2019. GDP - per capita (PPP) of china is $\$ 7,100$ in 2019 , $\$ 6,700$ in 2018 and $\$ 6,300$ in 2017 dollars $^{61}$. Indian GDP per capita is $\$ 16,500$ in $2019, \$ 15,600$ in 2018 and $\$ 14,700$ in 2017 dollars. Hence from the data, it can be concluded that India is Way ahead in terms of GDP per capita as compared to china. GDP of India - composition in agriculture: $14.8 \%$, industry: $26.7 \%$ and services: $46.5 \%$ (2019) dollars, as compared to GDP of china - composition in agriculture: $7.1 \%$, industry: $39.5 \%$ and services: $52.2 \%$ (2019) dollars. Hence from the above data, it can be concluded that the GDP of China in terms of composition in agriculture, industry, and services is almost double as compared to India. The population below the poverty line in India is $20.7 \%$ (2019), whereas the population below the poverty line in china is 3.3\% (2019). The inflation rate in India is $3.6 \%$ in 2019 and $4.4 \%$ in 2018 whereas that in china is $1.4 \%$ in 2019 and $2 \%$ in 2018. Labour force is 521.9 million in 2018 in India and 806.7 million for the same financial year in china. Therefore, the inflation rate is more and the labor force is less in India as compared to china. Public depth in India is $52.1 \%$ of GDP in 2018 and $51.3 \%$ in 2017 whereas that of China is $18.2 \%$ and $16.4 \%$ of GDP in 2018 and 2017 . Hence public debt of India is more than that of China ${ }^{62}$. External Debt of India is $\$ 474.4$ billion (31 December 2018 ) and $\$ 445.4$ billion (31 December 2017) and that of China is $\$ 1.638$ trillion (31 December 2018) and $\$ 1.457$ trillion (31 December 2017). Hence the external Debt of China is more than that of India. China's Economy is fourfold Larger Than India's Economy. The gross domestic product of India is near $\$ 1.5$ trillion $^{63}$. At the identical time, the gross domestic product of China is close to $\$ 7$ trillion.

China's rate has been systematically over India's growth rate over the past 3 decades more or less. India has barely overtaken the Chinese rate for a pair of quarters. Given that India will still beat the Chinese rate by an enormous margin for the subsequent 2 to 3 decades $^{64}$. From the angle of structural comparison, the most findings are The inner-urban financial gain difference in China and India country magnified within the 1980s, however, apparently, Indian urban difference is far over that of China, though the latter's difference is additionally increasing fast. Rural inequality within India and China nations would be similar however the distribution of inner-rural inequality represents a number of the regional variations in the two nations. In terms of financial gain or consumption, the gap between rural and concrete areas in India is smaller than that in China ${ }^{65}$. The regional disparities among the 2 nations are increasing step by step. In brief, institutional factors and therefore The government's biased policies have caused China's difference, whereas economic structures, unequal growth, and lack of education confirm India's difference.

\footnotetext{
$62 \mathrm{https}: / /$ www.indexmundi.com/factbook/compare/india.china, accessed on 14/09/2019

$63 \mathrm{https}: / /$ www.indexmundi.com/factbook/compare/india.china, accessed on 14/09/2019

64 Own Elaboration

65 Own Elaboration
} 
China's production Productivity is 1.6 times that of India. China produces plenty over India. The Indian production sector has multiple issues. These issues embody erratic electricity, slow and dear transport systems further as a lack of skills that increase production productivity. Given that an outsized portion of those issues is structural, it looks unlikely that India is going to be able to overcome them. Inflation in India is six times over it's in China. India's gross domestic product growth has been accompanied by runaway inflation within the country. The rate in the middle of inflation cannot last for an extended time. On the opposite hand, China's inflation has been comparatively stable at a negligible $0.8 \%$ for several years. This has been accomplished even though China has been recording a financial surplus for the past few years and ideally ought to be reeling with a high inflation rate. Given the fact that the Indian economy is severely marred by inflation, it looks unlikely that they'll be able to contend against China within the long term.

The yearly financial gain earned by the private sector in India is the lowest as compared to China. The survey discovered that in countries wherever regular employment was a lot of, the median per capita financial gain was stronger. In India, near $25 \%$ of the individuals had regular employment between 2008 and 2012, which is low compared with China. The survey conjointly highlighted an outsized distinction ${ }^{66}$. between a lot of economically. India's Gini constant rose to $51 \%$ by 2013 , from $45 \%$ in 1990 . China's Gini constant conjointly rose to $53 \%$ in 2013 , from $33 \%$ in 1990 China and India's net savings are positive and therefore the accounting includes a sufficiently broad variety of assets, hence financial aid is increasing. China has created spectacular gains in anticipation given the size of its territory and population. within the last half of the 20th century, China increased its average anticipation at birth from around 40 years to over 70 years. Arguably, enhancements within the provision of public health services, significantly in child and maternal health, are the largest factors in raising healthy life expectancy anticipation. In India life expectancy has increased over the years with men living longer by 6.9 years and girls by 10.3 years. Anticipation for individuals in India is 68.5 Years. Here China is the winner. In India and China, urban inequality is higher than rural inequality. Urban inequality, however, has tended to decline in China, whereas it has remained the same in India. In China, the rural-urban divide has increased from $4 \%$ to $34 \%$ in which explain overall wealth inequality, this trend is much less pronounced in India. Also, in China, inter-regional inequality has tended to stagnate, while in India, inter-state inequality has increased marginally.

The Chinese economy thrived on producing, the Indian economy was boosted by the sturdy growth in service ${ }^{67}$. Given this distinction, China includes a large advantage over the Republic of India within the production sector that is clear from its considerably higher share of worldwide manufacturing exports compared to India. Also, FDI inflows into China comprehensively exceed FDI inflows into the Republic of India, each in terms valuable likewise as a share of their several GDPs. However, the Republic of India scores on skillful and economical men, a gifted management system, a clear system of labor, cultural affinity and regulative setting. Additionally, Indian exports have remained buoyant within the face of competition from Chinese merchandise and a swiftness world economy, because of exporters differentiating merchandise and moving above the worth chain. India, being conscious of the importance of producing economic development and job creation, has taken steps to push producing, like encouraging foreign collaborations with the aim of technology transfer.

\footnotetext{
$66 \mathrm{https}: / /$ www.indexmundi.com/factbook/compare/india.china, accessed on 14/09/2019

${ }^{67}$ Own Elaboration
} 
Overall wealth is more unequally distributed in India compared to China. This is a contrast with the distribution of income in the two countries. Income/consumption inequality in China is much higher than that in India. There is a convergence between China and India in terms of wealth inequality. In both countries, buildings and financial assets are important sources of overall wealth ${ }^{68}$. What is, however, different in India is that the land was, and continues to be, a major source of inequality, whereas, in China, land inequality in rural areas is not as important in 2019 as it was in 1995.

China and India need to break away from increased inequality if they have to be true to their claims of creating egalitarian societies ${ }^{69}$. The main policy prescription is that both countries should urgently focus on shoring up agricultural populations in terms of their incomes as well as assets. In the case of China, such policies will serve to reduce the rural-urban gap, which is the main source of the increasing trend in wealth inequality. India, provide additional support structures through right state policies and radical policies of land redistribution, greater distribution equality can be restored. By improving both incomes as well as asset distribution in rural areas, both countries will witness a reduced rural-urban gap but also the process of distress migration that goes a long way in increasing intra-urban disparities.

From the paper it can be concluded that China is economically ahead of India in terms of Labour product, employment, Gross Domestic Product, adjusted net saving, life expectancy, Income Gini, Wealth Gini, Depth ratio, public depth and low poverty rate as compared to India. Whereas, India is economically ahead of China in terms of the carbon intensity of the Gross Domestic Product. Hence China has lead over India in terms of economic competitiveness.

68 Own Elaboration

69 Own Elaboration 


\section{References:}

1. Abbas. S., Horton. M., Historical Patterns and Dynamics of Public Debt-Evidence from a New Database. IMF Economic Review, 2011.

2. Adam. P., Become. W., Economic growth, industrial structure, and technical efficiency: empirical evidence from Ghana, Senegal, and Morocco on the causal dynamics, 2012

3. Alcoser. J., Monitors opportunities in India. Harvard Business School Case, 2008.

4. Amity. M., and Freund. C., The anatomy of China's export growth role in world trade, 2010

5. Banerjee. A.V., Policies for a Better-Fed World. Review of World Economics, Mumbai 2016. https://doi.org/10.3386/w21623

6. Barthelemy. J., Demerger. S., Foreign Direct Investment and Economic Growth: Theoretical Issues and Empirical Application to China. Review of Development Economics. 2000. https://doi.org/10.1111/1467-9361.00083

7. Bowles, P., Re-balancing China's growth: Some unsettled questions. Canadian Journal of Development Studies, 2012. https://doi.org/10.1080/02255189.2012.660874

8. Chen. S., Wang. Y., 2001. China's growth and poverty reduction: recent trends between 2000 and 2018. WBI-PIDS Seminar on Strengthening Poverty Data Collection and Analysis held in Manila, Philippines, 2001.

9. Christina. C., The Impacts of High Growing Government Debt on Economic Growth: An Empirical Investigation of the Euro Area, ECB Working paper series No. 1237, 2010.

10. Dhiraj. J., Nair. K., Factors Affecting GDP (Manufacturing, Services, Industry): An Indian Perspective, Mumbai 2012

11. Dixit. A., Investment and Employment Dynamics in the Short Run and the Long Run in China. Oxford Economic Papers, 1997. https://doi.org/10.1093/oxfordjournals.oep.a028592

12. Dresher. K., Singh. S., Study of Poverty in India. International Journal of Current Research, 2018.

13. Fernald. J., Louganis. P., China, and emerging Asia: Comrades or competitors? Federal Reserve Bank of Chicago, New York 2003. https://doi.org/10.2139/ssrn.484503

14. Guan. D., Liu. Z., The gigatons gap in China's carbon dioxide inventories. Nature Climate Change, 2012. https://doi.org/10.1038/nclimate1560

15. H. Venkat Subbiah, Enterprise, and Economic Change: 50 Years of FICCl (New Delhi: Vikas Publishing House, 1977), pp. 169-72.

16. Khanna. T., China, and India, the power of two. Harvard Business Review, 2009

17. Kochanski. S., Liberalization and Business Lobbying in India. New Delhi: Oxford University Press, 2007.

18. Kohli, A., State, and Redistributive Development in India. Basingstoke: Palgrave Macmillan, 2012. https://doi.org/10.1057/9781137000767_7

19. Kraal. A., Household Saving in China. The World Bank Economic Review, 2000. https://doi.org/10.1093/wber/14.3.545

20. Kwan. A. C., Cots mitis. J. A., Economic growth and the expanding export sector. International Economic Journal, 1991.

21. Nilekani, N., Imagining India: Ideas for the new century. International Business 6th edition, New Delhi 2013.

22. Paul. J., Gupta. P., Economic Environment \& Policies for Business. McGraw-Hill, New Delhi 2013.

23. Rosarian. J., Study on Poverty and Hunger in India. Mediterranean Journal of Social Sciences, Kerala 2013

24. Singh. G., Paul. J., Foreign direct investments in India. Smart Journal of Management, Gujarat 2014.

25. Song. X., Interrelations between Development of Western China and Improvement of Health Level, Population and Economics, 2000.

26. Venkat Subbiah. H., Enterprise and Economic Change: 50 Years of FICCl. Vikas Publishing House, New Delhi, 1977.

27. Yao. S., economic growth, FDI and exports in India. Applied Economics, 2006. https://doi.org/10.1080/00036840500368730 
28. Zhao. Y., Nielsen. C., China's $\mathrm{CO} 2$ emissions estimated from the bottom up Recent trends, spatial distributions, and quantification of uncertainties. Atmospheric Environment Journal, 2012. https://doi.org/10.1016/j.atmosenv.2012.05.027

\author{
Netography: \\ 1. https://economicpoint.com \\ 2. https://economics.rabobank.com \\ 3. https://www.forbes.com \\ 4. https://www.livemint.com \\ 5. https://visual.ly \\ 6. https://thediplomat.com \\ 7. https://www.rba.gov.au \\ 8. https://www.indexmundi.com \\ 9. https://www.conference-board.org \\ 10. https://www.economist.com \\ 11. https://www.jagranjosh.com
}

\title{
List of figures
}

Figure 1: Economic Factors affecting competitiveness

Figure 2: Figure of India

Figure 3: Measuring India's GDP (\%)

Figure 4: GDP Components

Figure 5: Invert Direct Investment in India

Figure 6: Import and Export Performance

Figure 7: GDP Growth in India from 1990 to 2016

Figure 8: Equality in Income and Employment Share of India

Figure 9: People Lifted Out of Poverty Between 1990 and 2018 in India

Figure 10: Economic Debt Ratio in the percentage of GDP in India

Figure 11: Carbon Dioxide Emissions

Figure 12:Flag of China

Figure 13: Real Per Capita GDP 2018 of China

Figure 14: Chinese Infant Mortality

Figure 15: Real GDP Per Capita of China in 2018 in Million

Figure 16: People Lifted Out of Poverty Between 1990 and 2018

Figure 17: Adjusted Net Saving of China

Figure 18: Debt ratio of China

Figure 19: Carbon Emission Intensity

\section{List of tables}

Table 1: Competitiveness ranks of India and select countries

Table 2: Population, GDP, and GDP per capita at market prices selected years

Table 3:GDP per capita (constant 2000 US\$), selected comparisons

Table 4: Population living on less than $\$ 1.25$ a day in South Asia

Table 5: GDP in 2018 (Trillion United States Dollar)

Table 6: Percentage increase in Labour Market (2010-2018)

Table 7: Employment in India and China in Millions (2010-2018)

Table 8: Median Household Income Rank of India and China

Table 9: Income Gini of India and China (2000 and 2018)

Table 10: Poverty rate of India and China (1981-2018)

Table 11: Public Debt of India and China (2018)

Table 12: Debt Ratio of India and China (2010-2018)

Table 13: Carbon Intensity of GDP India and China (2010-2018) 